\title{
Paleotsunami Inundation of a Beach Ridge Plain: Cobble Ridge Overtopping and Interridge Valley Flooding in Seaside, Oregon, USA
}

\author{
Curt D. Peterson, ${ }^{1}$ Harry M. Jol, ${ }^{2}$ Tom Horning, ${ }^{3}$ and Kenneth M. Cruikshank ${ }^{1}$ \\ ${ }^{1}$ Geology Department, Portland State University, 1721 SW Broadway, Portland, OR 77207, USA \\ ${ }^{2}$ Geography Department, University of Wisconsin at Eau Claire, P.O. Box 4004, Eau Claire, WI 54702, USA \\ ${ }^{3}$ Horning Geosciences, 808 26th Avenue, Seaside, OR 97138, USA
}

Correspondence should be addressed to Curt D. Peterson, petersonc@pdx.edu

Received 4 February 2010; Revised 6 June 2010; Accepted 10 August 2010

Academic Editor: Steven L. Forman

Copyright ( $) 2010$ Curt D. Peterson et al. This is an open access article distributed under the Creative Commons Attribution License, which permits unrestricted use, distribution, and reproduction in any medium, provided the original work is properly cited.

\begin{abstract}
The Seaside beach ridge plain was inundated by six paleotsunamis during the last $\sim 2500$ years. Large runups (adjusted $>10 \mathrm{~m}$ in height) overtopped seawardmost cobble beach ridges ( $7 \mathrm{~m}$ elevation) at $\sim 1.3$ and $\sim 2.6$ ka before present. Smaller paleotsunami (6-8 $\mathrm{m}$ in height) likely entered the beach plain interior (4-5 m elevation) through the paleo-Necanicum bay mouth. The AD 1700 Cascadia paleotsunami had a modest runup (6-7 m height), yet it locally inundated to $1.5 \mathrm{~km}$ landward distance. Bed shear stresses (100-3,300 dyne $\left.\mathrm{cm}^{-2}\right)$ are estimated for paleotsunami surges (0.5-2 m depths) that flowed down slopes (0.002-0.017 gradient) on the landward side of the cobble beach ridges. Critical entrainment shear stresses of 1,130-1,260 dyne $\mathrm{cm}^{-2}$ were needed to dislodge the largest clasts $(26-32 \mathrm{~cm}$ diameter) in paleotsunami coulees that were cut $(100-200 \mathrm{~m}$ width) into the landward side of the cobble ridges.
\end{abstract}

\section{Introduction}

In this paper, we present the results of investigating paleotsunami inundations that crossed multiple beach ridges and flooded intervening valleys in a low-elevation beach ridge plain. The resort town of Seaside, Oregon, with a summer population of up to 50,000 , is developed on a prograded beach ridge plain (Figure 1). This low-elevation plain has experienced both historical (1964) farfield tsunami [1] and nearfield paleotsunami (4-5 Cascadia events during the last $2,500 \mathrm{yr})[2-5]$.

Inundation from the historical farfield tsunami (1964 Gulf of Alaska rupture) in Seaside was limited to flooding of the small Necanicum Bay mouth and two interridge valley channels [1]. Several of the nearfield Cascadia paleotsunami crossed the beach plain (1.5 km in width) [4]. However, previous work has not established whether the beach plain inundation occurred by (1) direct overwash of the seawardmost cobble beach ridges, or (2) bay mouth flooding and shore-parallel flow within the interridge valleys [5]. Discrimination of these two mechanisms is important to documenting paleotsunami runup heights and to proposing specific evacuation strategies for coastal populations in low elevation settings of beach ridge plains.

In this paper, we present records of paleotsunami deposits, which are distributed landward of stable cobble ridges in the Seaside beach plain [6]. These data establish the minimum overtopping heights and bed shear stresses of the paleotsunami flows. In this coble ridge plain the thin paleotsunami sand layers are locally preserved in intertidal wetlands and supratidal spruce-tree bogs that occur in shoreparallel interridge valleys. The deposits do not demonstrate simple trends of landward thinning or continuity along the interridge valleys [5].

Tsunami deposition is highly variable in such beach ridge settings [13], leading to uncertainty of paleoflow dynamics. Nevertheless, tsunami deposit mapping constrains predicted minimum flow hazards and is needed to supplement the 


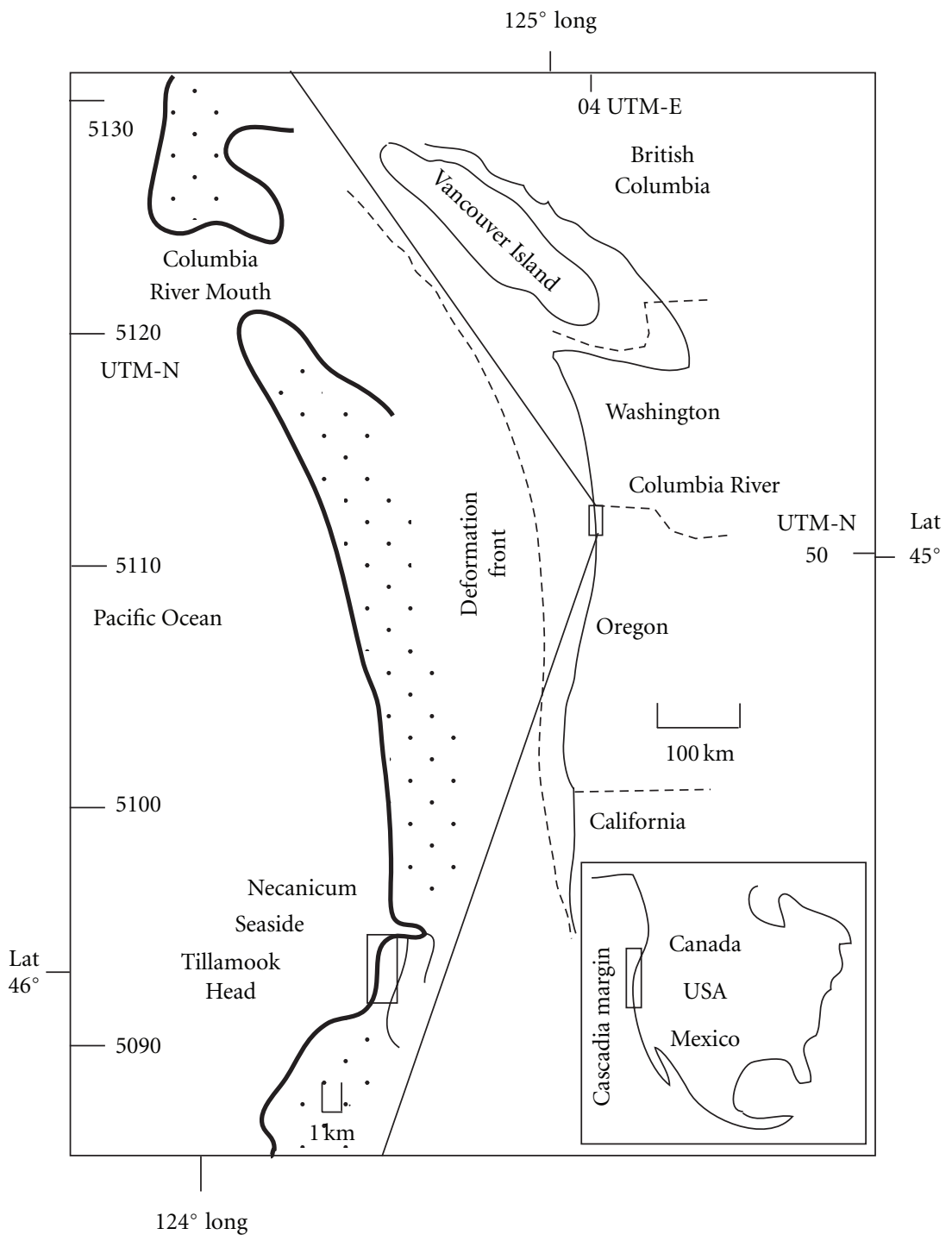

FIGURE 1: Location map of Seaside (boxed study area) at the southern end of the Clatsop beach-ridge plains (bold shoreline), located south of the Columbia River mouth. The study area is located near the center of the Cascadia subduction zone (inset) that extends $\sim 1,000 \mathrm{~km}$ from Vancouver Island in British Columbia to northernmost California. The offshore deformation front of the subduction zone is shown by a bold dashed line. The Seaside population, up to 50,000 people, is expected to have $\sim 25$ minutes to evacuate following seismic shaking, before the onset of tsunami inundation [6]. Map coordinates include reference longitude and latitude and UTM Northings at $10 \mathrm{~km}$ intervals for the Clatsop Plains.

numerically modeled inundations of beach plains, such as at Seaside [14]. Beach ridge plains proved to be amongst the most dangerous of tsunami inundation settings during the recent (2004) Indian Ocean tsunami [15].

\section{Previous Work}

Three factors contribute to a high tsunami risk in the Seaside beach ridge plain, including low elevation, large population, and interridge channels that restrict rapid evacuation at bridge crossings (Figure 2). These risk factors focused research attention on Seaside, leading to the first field evidence of paleotsunami overland inundation beyond tidal marshes in the Cascadia margin $[2,4]$. However, the specific mechanisms of beach plain inundation by beach ridge overtopping, and/or by interridge valley flooding were left unresolved [5]. The uncertainty resulted from conflicting evidence of paleoflow indicators. Paleotsunami sand-sheets in Seaside are discontinuous across the cobble beach ridges, and are generally thin, averaging only several centimeters in thickness. Furthermore, the paleotsunami sand layers vary greatly in thickness $(0.25-30 \mathrm{~cm}$ thick) along short distances $(\sim 100 \mathrm{~m})$ of the interridge valley wetlands [4]. Cobbles are locally embedded in paleotsunami sand layers, such as between core sites NW2 and NW7, near the back-edge of the beach plain.

Sand fractions of the paleotsunami deposits (125-350 $\mu \mathrm{m}$ in grain size) reflect both beach and river sand sources. The 
TABLE 1: Radiocarbon dated samples from Seaside, Oregon.

\begin{tabular}{|c|c|c|c|c|c|c|}
\hline Site name & Depth $(\mathrm{cm})$ & Material type & $\mathrm{C} 14 \pm$ yr PB & Calibrated ${ }^{*}$ cal yr BP $2 \sigma$ & Lab no. beta- & Ref. \\
\hline Covej40b & 143 & Cone & $1230 \pm 40$ & $1060-1260$ & 198700 & 4 \\
\hline Covej40b & 228 & Cone & $2770 \pm 40$ & $2780-2950$ & 198701 & 4 \\
\hline Palmrose & Base & Midden & $\sim 3,650$ & & & 1 \\
\hline Palmrose & Top & Midden & $\sim 1,600$ & & & 1 \\
\hline 832 & 90 & Peat & $590 \pm 70$ & $515-668$ & 96840 & 3 \\
\hline NW2 & 48 & Peat & $480 \pm 60$ & $326-644$ & 42112 & 2 \\
\hline NW2 & 70 & Peat & $800 \pm 60$ & $657-904$ & 42113 & 2 \\
\hline NW2 & 111 & Peat & $1100 \pm 70$ & $804-1230$ & 42088 & 2 \\
\hline NW2 & 158 & Peat & $1370 \pm 70$ & $1094-1409$ & 44595 & 2 \\
\hline NW2 & 268 & Peat & $2000 \pm 70$ & $1749-2148$ & 42114 & 2 \\
\hline AveQ & Base & Midden & $\sim 3,250$ & & & 1 \\
\hline AveQ & Top & Midden & $\sim 1,160$ & & & 1 \\
\hline j22 & 72 & Leaf & $150 \pm 30$ & $60-290$ & 194483 & 4 \\
\hline j4 & 230 & Twig & $210 \pm 40$ & $136-315^{\wedge}$ & 194481 & 4 \\
\hline 823 & 74 & Peat & $450 \pm 60$ & $312-625$ & 96835 & 3 \\
\hline j49 & 410 & Org.Mud & $680 \pm 40$ & $540-660$ & 198699 & 4 \\
\hline j69 & 70 & twig & $1530 \pm 40$ & $1320-1520$ & 198698 & 4 \\
\hline 716 & 81 & Peat & $360 \pm 70$ & $292-518$ & 96837 & 3 \\
\hline 879 & 54 & Peat & $480 \pm 90$ & $316-653$ & 99234 & 3 \\
\hline
\end{tabular}

Core sites and core logs are shown in Figure 2. Sample position is presented in depth $(\mathrm{cm})$ below surface.

Calibrated years BP starts at 1950 AD.

Some event ages are approximated to $1000 \mathrm{yr} \mathrm{BP}(\mathrm{ka})$ in the text.

References (Ref): (1) [9, 11]; (2) [2]; (3) [4], (4) [6].

$*$ Radiocarbon Calibration from CALIB 5.0.2 [12].

${ }^{\wedge}$ Radiocarbon calibrated age (j4) for older peak (81\% probability distribution) of bimodal curve.

TABLe 2: Central Cascadia subsidence and paleotsunami events for the last $\sim 2,500$ years.

\begin{tabular}{|c|c|c|c|c|c|}
\hline Event number & Regional subsidence & $\begin{array}{l}\text { Seaside subsidence } \\
\text { core site record }\end{array}$ & Regional tsunami & $\begin{array}{l}\text { Seaside tsunami } \\
\text { core site record }\end{array}$ & Event age \\
\hline Historic & None & na & Farfield & $\mathrm{j} 14$ & $1964 \mathrm{AD}$ \\
\hline$\# 1$ & Large & NW2 & Nearfield & NW2, NW7 & AD 1700 \\
\hline$\# 2 \mathrm{a}$ & None & na & Source? & NW2 & $\sim 0.8 \mathrm{ka}$ \\
\hline$\# 2 \mathrm{~b}$ & Medium & NW2 & Nearfield & NW2, NW7 & $\sim 1.1 \mathrm{ka}$ \\
\hline$\# 3$ & Small & - & Nearfield & $\mathrm{NM} 2, \mathrm{j} 40 \mathrm{~b}$ & $\sim 1.3 \mathrm{ka}$ \\
\hline$\# 4$ & Large & NW2 & Nearfield & NW2 & $\sim 1.7 \mathrm{ka}$ \\
\hline$\# 5$ & Medium & - & Nearfield & j40b & $\sim 2.6 \mathrm{ka}$ \\
\hline
\end{tabular}

Coseismic subsidence from event \#1 at AD 1700 is estimated to be $1.0 \pm 0.5 \mathrm{~m}$ in Seaside [16].

Regional central Cascadia data from [8].

Regional subsidence event dates [26].

Overland paleotsunami events $[7,27]$.

Seaside core site references: NW2, NW7 [2]; j14, j40b [6].

Seaside core sites are shown in Figure 2, except for site j14, which is shown later in Figure 11.

Seaside core logs and radiocarbon ages are shown in Figure 3, except for j14, which is shown later in Figure 10.

heavy-mineral fractions in selected paleotsunami deposits range from 25 to 87 percent beach sand component by weight (Figure 3) [3]. The river sand fractions were presumably entrained from the Necanicum and upper Neawanna channel bottoms by paleotsunami surges. Weathered gravel and oxidized soil peds occur in paleotsunami sand layers (\#1, $\# 2$, and \#3) in sites NW2 and NW7. The soil peds could represent backwash from hill slopes at the landward edge of the beach plain (Figure 2). The dated paleotsunami layers in the Neawanna wetlands extend back to $2 \mathrm{ka}$ (Table 1 ). All core data presented in this paper are referenced to original core logs as shown in the caption of Figure 3.

Adding to the difficulties of paleotsunami deposit mapping in the Seaside beach plain are (1) bioturbation of paleotsunami deposits in supratidal soils, and (2) coseismic liquefaction of paleotsunami sand layers and underlying sand units [5]. Liquefaction disturbance including intruded contacts can occur in thin tsunami sand layers $(1.0 \mathrm{~cm}$ 


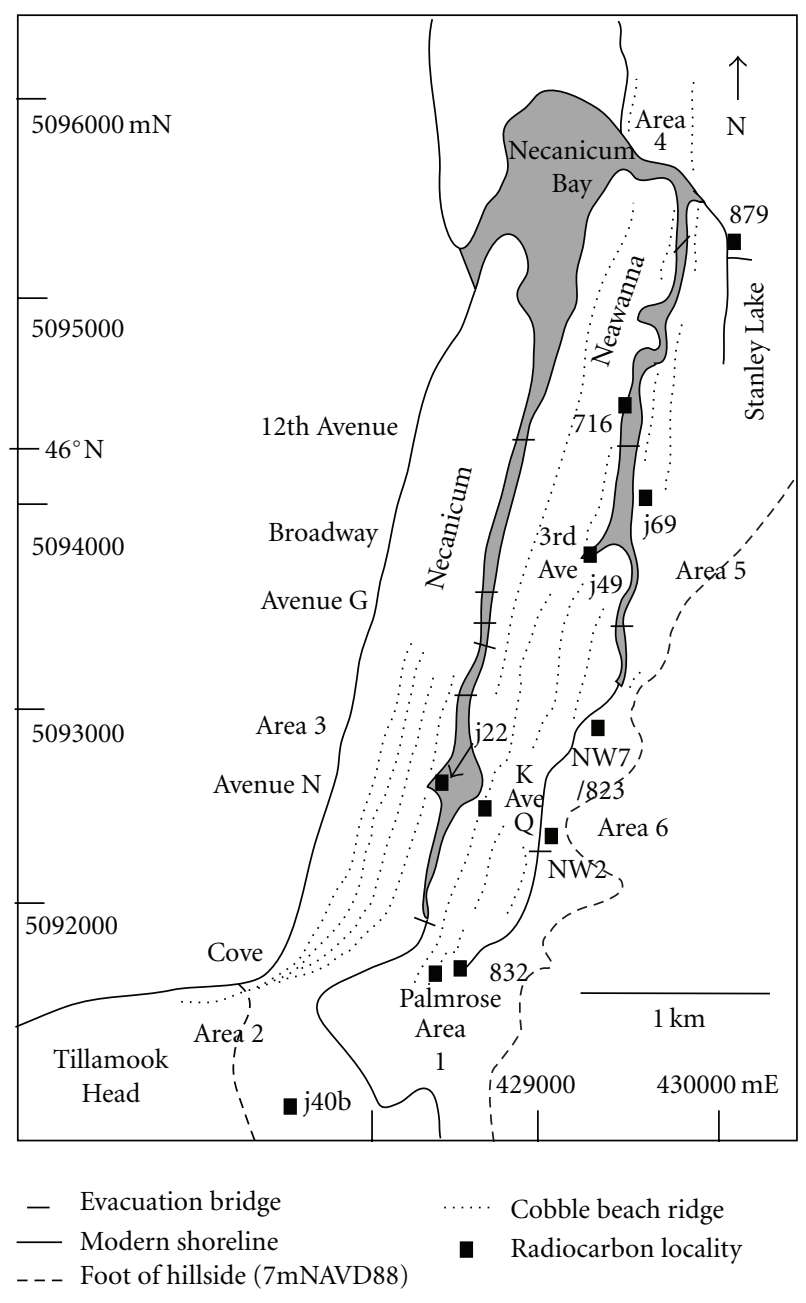

FIGURE 2: Map of Seaside beach ridge plain with modern shoreline (bold line), cobble beach ridges (dotted lines), and dated core sites (solid squares), and selected overtopping Areas 16. Evacuation routes, over bridges (short bold lines), cross the intertidal Necanicum and Neawanna channels. Map coordinates are in NAD83 in UTM (meters), with latitude and longitude reference points (degrees). Palmrose and Avenue Q are Native American midden sites that are preserved on cobble ridges (4-5 m elevation NAVD88). The seawardmost, cobble beach ridges are 6$7 \mathrm{~m}$ elevation. The fluvial-tidal wetlands in the interridge valleys (Necanicum and Neawanna) are of 2-3 m elevation. See Figure 4 for satellite image of study locality. See Figure 3 for core logs and cited sources of the core log data. See Table 1 for radiocarbon data.

thick), where they are buried by significant overburden (0.5$1.0 \mathrm{~m}$ depth) prior to seismic shaking. Dense sampling of target paleotsunami layers from multiple core sites at $\sim 50 \mathrm{~m}$ intervals has helped to resolve these record preservation problems in nearby beach plains [7].

In 2004 a pilot study of potential tsunami inundation in the Seaside study area was initiated by several US federal agencies [6]. As part of the multiagency study, the known AD 1700 paleotsunami sand layers were field checked and additional paleotsunami sites were mapped for evidence of beach ridge overtopping. In this paper, we integrate results form the several studies above to establish the range of flooding mechanisms and flow conditions that occurred in the Seaside beach plain locality.

The criteria used to identify paleotsunami deposits in beach plain settings of the study area are provided in previous papers $[7,8]$. Data on paleotsunami deposit tracers in Seaside, including marine diatoms, sand mineralogy, and subsidence event stratigraphy are documented in earlier studies [2-4]. Details on paleotsunami core site coordinates, core logs, cut bank sections, and radiocarbon dating in Seaside are provided in the Tsunami Pilot Study [6]. Numericalmodeling has recently been used to estimate potential tsunami inundation produced by hypothetical probabilistic ruptures of the Cascadia megathrust fault [14]. The results from this presentation of the geologic inundation records that are preserved in the beach ridge plain can be compared to the numerically modeled tsunami hazards in Seaside.

\section{Beach Plain Geomorphology and Paleotsunamis}

Beach ridges in the Seaside study area were formed by cobbles and boulders that were derived from landslides shed off from the basaltic Tillamook Headland to the south of the beach ridge plain (Figure 2). The wave worked basaltic debris, typically ranging from 5 to $50 \mathrm{~cm}$ in diameter, was carried to the northeast alongshore ( $1-5 \mathrm{~km}$ distance) by large surf to form the beach cobble ridges [4]. Wave refraction focuses wave energy towards the Tillamook Headland, yielding cobble ridges of $7 \mathrm{~m}$ elevation NAVD88 at the Cove. (The NAVD88 datum $(0 \mathrm{~m})$ used in this study is equivalent to one meter below mean sea level, or $-1 \mathrm{~m}$ relative to the earlier NAVD29 datum. The NAVD88 datum is also equivalent to mean low tide water (MLW) in the study area.)

Sustained storm-surge or set-up in northern Oregon reaches only 1-2 m above predicted tides [8]. Individual wave-swash runup extends above the reach of storm surge, helping to build the cobble ridges to 6-7 $\mathrm{m}$ elevation. Tidal inlet excursions $(\sim 0.5 \mathrm{~km}$ distance) to the north and south of its present position have occurred during the last several decades. Maximum tidal range at Seaside is $3 \mathrm{~m}$. River floods impact the Necanicum River floodplain south of Seaside, but have not exceeded a height of $4.5 \mathrm{~m}$ NAVD88 in the Necanicum or Neawanna fluvial-tidal channels in historical time [16].

Net shoreline progradation of the southern Clatsop Plains produced at least three sets of cobble beach ridges in the Seaside area (Figure 2). Abandoned foredunes do not extend south of the Necanicum River mouth [17, 18]. Shell middens at two cultural sites, Palmrose and Avenue $\mathrm{Q}$, are preserved on top of the middle set of cobble ridges located between the Neawanna and Necanicum channels (Figure 2). The radiocarbon dated middens yield occupation dates of 3,650-1,650 yr BP (Palmrose) and 3,280-1,160 yr BP (Avenue Q) (Table 1) [9, 11]. The cobble beach ridges located landward of the present Necanicum River channel were abandoned by shoreline progradation prior to $3 \mathrm{ka}$.

Dated events of abrupt regional subsidence $(0.5-1.5 \mathrm{~m})$, as recorded in tidal marshes, and associated sand capping 


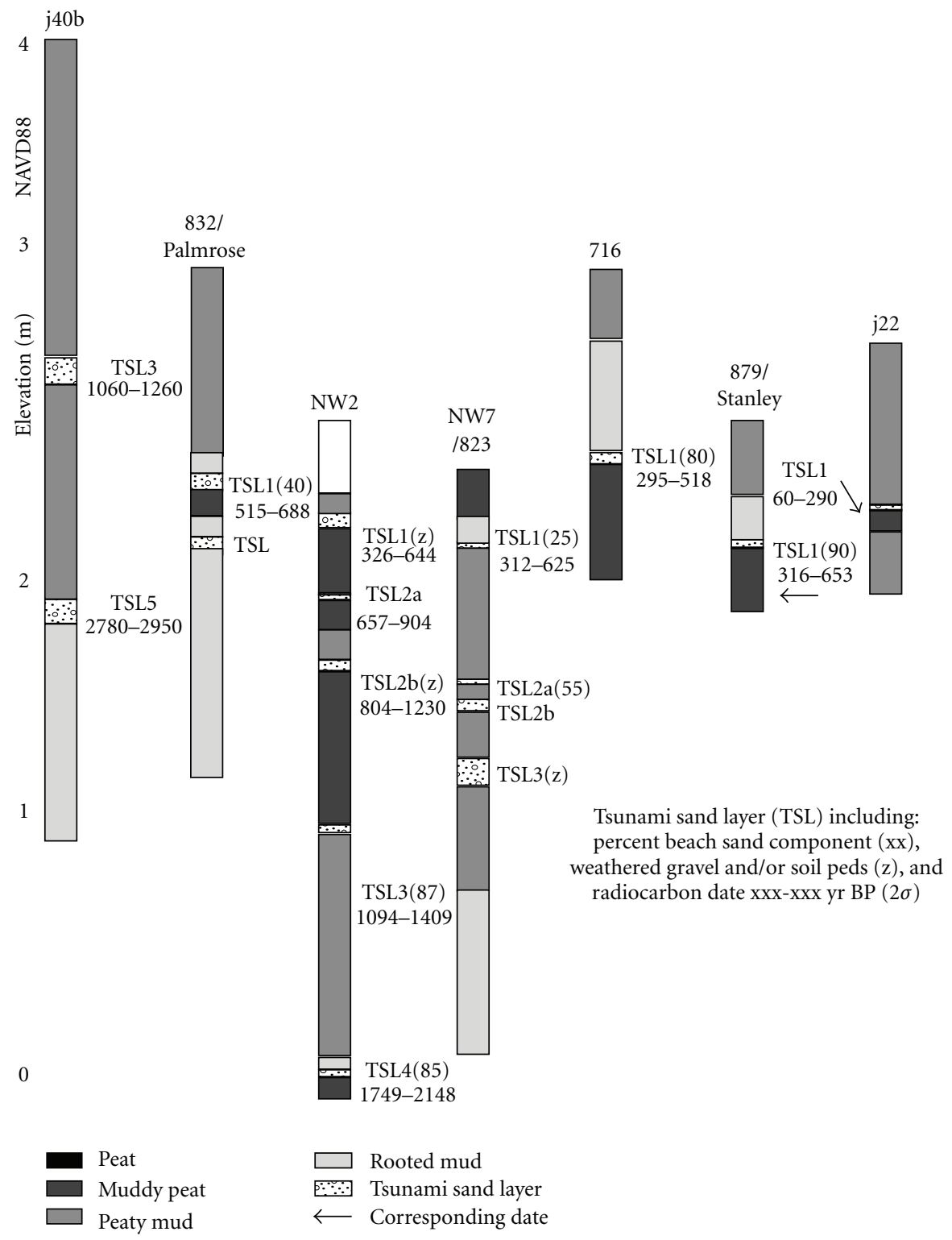

Figure 3: Core logs including dated paleosubsidence and paleotsunami sand layers in reported core sections from representative sites in the Seaside beach plain. Four of the five tsunami sand layers (TSL) are associated with regionally correlated coseismic subsidence horizons dated from $\sim 0.3$ to $2 \mathrm{ka}$. One weakly developed paleotsunami sand layer (TSL2a) is not associated with a paleosubsidence horizon [7, 8]. See Figure 2 for core site locations and see Table 1 for radiocarbon data. Core logs, radiocarbon dates, and paleotsunami sand source mineralogy data are from sites NW2, NW7, 832, 879 [2, 3, 9], sites 832, 716, and 879 [4], and from sites j40b and j22 [6]. All additional figures use the same core log citations: NWx for [2,3] xxx for [4] jxx for [6].

layers, identified as paleotsunami deposits (Figure 3), are correlated to regional Cascadia ruptures (Tables 1 and 2) $[2,4,16]$. Shorter records of paleosubsidence, including 23 buried marshes, extend the paleotsunami record back to 1,100 or $1,300 \mathrm{yr}$ BP in the northern and southern Neawanna wetlands. Only the last Cascadia subsidence event at $\mathrm{AD}$ 1700 [19] has been identified in cores from the seawardmost Necanicum tidal wetlands.

The Necanicum River flowed westward along the north flank of the Tillamook Headland prior to bog development by $\sim 2.8 \mathrm{ka}$ in core $40 \mathrm{~b}$ (Figures 2 and 3 ). Following an avulsion and/or rivermouth blockage by beach ridge accretion the Necanicum River angled back to its present course through Seaside (Figure 2). During winter floods the overflow from the Necanicum River discharges into the interridge valley containing the Neawanna channel [16]. Both the Necanicum and Neawanna channels converge at the small Necanicum Bay. Narrow uppertidal to supratidal marshes occur in the Necanicum and Neawanna interridge valleys [4]. Spruce bogs occur in the abandoned, south Necanicum valley, the Palmrose Bogs, and at the back-edge of the beach plain. Peaty muds record a net rise of sea level 


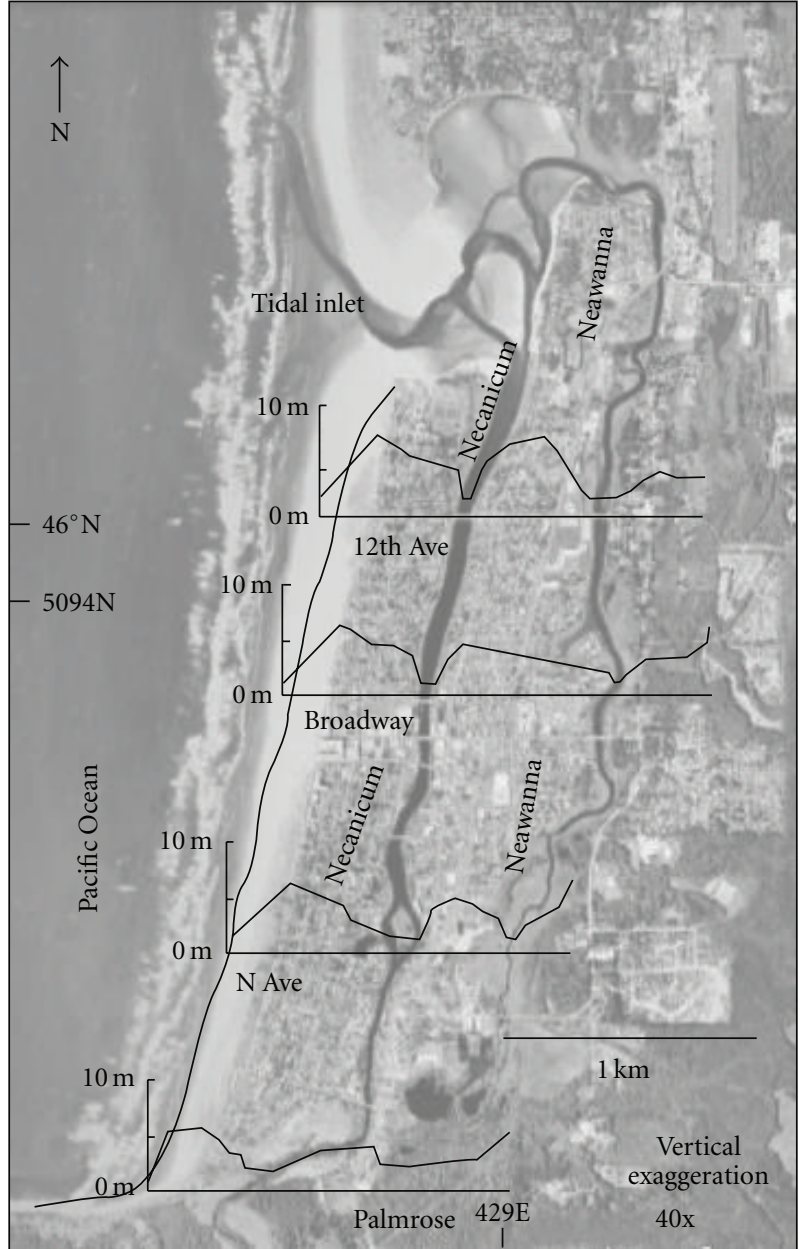

FIGURE 4: West-east topographic profiles across the Seaside beach plain at selected locations: 12th Avenue, Broadway Avenue, Avenue $\mathrm{N}$, and the Palmrose midden site. See Figure 2 for location positions in the Seaside beach plain. Vertical elevation $1-10 \mathrm{~m}$ is based on the NAVD88 datum. Vertical to horizontal exaggeration of profile scale is 40x. The interridge valleys of the Necanicum and Neawanna are particularly susceptible to tsunami flooding from (1) overtopping of the seawardmost beach ridges, and/or (2) sustained flow through the Necanicum Bay tidal inlet, north of 12th Avenue (Figure 2). Base image is from Google Earth.

$(\sim 1 \mathrm{~m} / 1000 \mathrm{yr})$ in the tidal marshes of the intertidal Neawanna channel (Figure 3) [2].

Cobble ridge crests increase from elevations of 3-4 m elevation in the landwardmost beach ridges to $6-7 \mathrm{~m}$ in the seawardmost beach ridges (Figure 4 ). The seaward increase in cobble ridge crest height is due to the rise of relative sea level (3-4 $\mathrm{m}$ ) since the onset of beach plain progradation at $4 \mathrm{ka}$ [20]. The lower elevations of the beach plain interior greatly increase the flooding hazard from tsunami that overtop the seawardmost cobble ridges, and/or flow into the beach plain interior through the Necanicum tidal inlet (Figure 2). This study focuses on paleotsunami currents that overtopped shore-parallel beach ridges and flowed down the landward sides of the overtopped beach ridges.

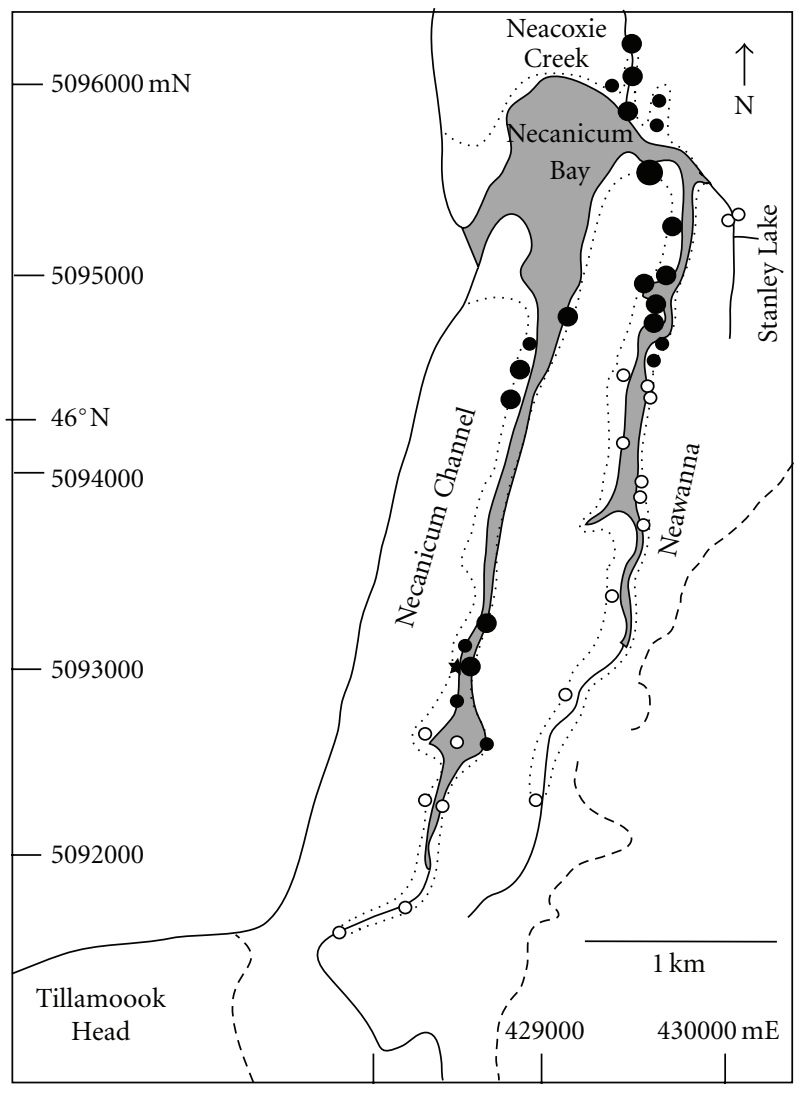

$$
\begin{aligned}
& 1964 \text { tsunami sand } \\
& \text { layer thickness } \\
& \text { o tsunami sand } \\
& \text { - }<1 \mathrm{~cm} \\
& \text { - } 1-10 \mathrm{~cm} \\
& >10 \mathrm{~cm}
\end{aligned}
$$

FIGURE 5: Map of 1964 maximum highwater line and tsunami sand layer (TSL) deposits in the Seaside beach ridge plain. Inundation was limited to the Necanicum Bay, and the Necanicum and Neawanna interridge valleys $[5,6]$. Preserved sand layers from the 1964 event do not reach the full extent of the mapped tsunami flooding in either the Necanicum or Neawanna interridge valleys.

\section{Paleotsunami Flow Relations}

4.1. Topographic Control. High-resolution topographic control is required for analysis of paleotsunami runup height and flow stress. High-resolution topography ( $0.6 \mathrm{~m}$ contour interval) is available for the Seaside beach plain $(1: 1,200$ scale) from orthorectified photogrammetric methods [21]. The photogrammetric analysis reduces effects from artificial topography, such as buildings, in the densely developed beach ridges. Paleotsunami overtopping sites are compared to corresponding elevations along abandoned beach ridge crests. The restricted overtopping provides both maximum and minimum estimates of paleotsunami runup heights across the beach ridge plain (Figure 4). The differences between runup heights and ridge elevations yield estimated flow depths. Specifically, a ridge segment of known height 


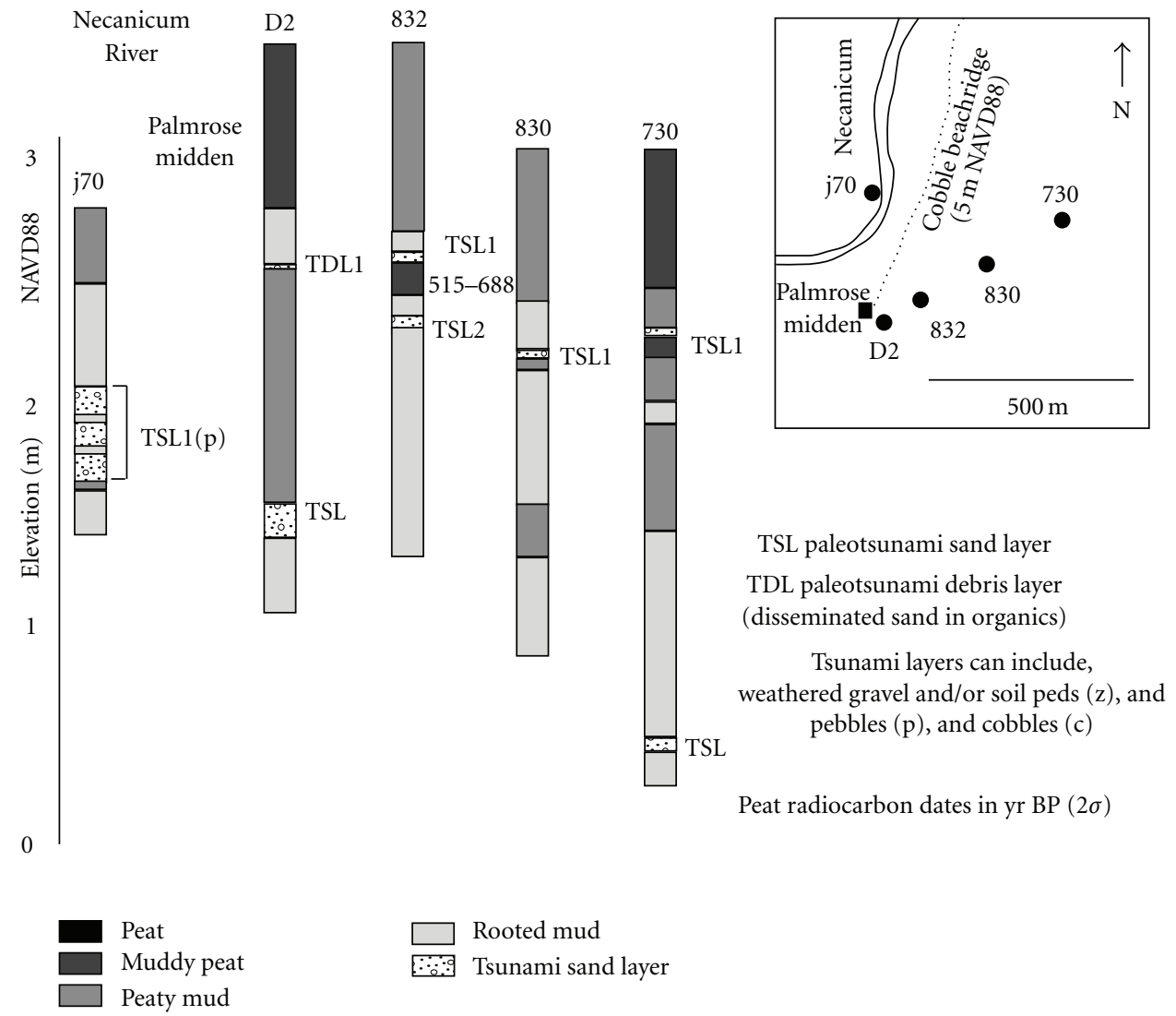

Figure 6: Core logs and inset site map from the Palmrose bogs (overtopping Area 1). Sites include j70 [6], D2 [2, 9], sites 832, 830, 730 [4]. See Figure 2 for area location and Table 1 for radiocarbon data.

that is, apparently overtopped provides a minimum runup height. An adjacent ridge segment of greater height, that is, not apparently overtopped provides a maximum limiting runup height. The topographic maps also provide slope angles on the landward sides of the abandoned beach ridges. The slope angles are needed to evaluate flow forces for different water column depths as outlined below.

4.2. Tractive Force Estimation. Paleotsunami shear stresses are estimated using the DuBoys tractive force relation for flow down the cobble ridge slopes (Table 3). Water slope is assumed to approximately follow ground surface gradients on the landward side of the beach ridges (Figure 4). Hydraulic head from tsunami surge bores could increase the water slope. Such potential bore effects are not included in this study, leading to more conservative estimates of the bottom shear stresses. Paleotsunami return flows to the ocean via the interridge valleys and the Necanicum Bay mouth are not addressed in this paper. We are primarily concerned with hazards resulting from the initial inundation(s) of the beach plain.

4.3. Critical Entrainment Relations. Bimodal transport and deposition of cobbles and/or boulders in paleotsunami sandsheets are reported from many localities worldwide [22]. Such bimodal transport and deposition likely occur under sustained sheet flow conditions, where some gravel and abundant sand are in supply. We use published relations for the entrainment of large clasts to establish critical shear stresses in the Seaside beach ridge plain. A form of the Shields (1936) entrainment equation as modified by Miller et al. [23] and amended for bed material size by Komar [24, 25] is used to estimate the critical entrainment stresses for deposits containing a range of grain sizes (Table 3 ).

The calculations for critical entrainment stress used in Seaside are based on clast intermediate diameters $\left(D_{m}\right)$, as measured from exposed beach ridge crests, shallow trenches, or channel cutbanks.

Rounded, equant-to-ellipsoidal basalt clasts $\left(2.85 \mathrm{~g} \mathrm{~cm}^{-3}\right.$ density) are used for the clast size analysis. At least 25 clasts were measured from representative sample sites $\left(0.25 \mathrm{~m}^{-2}\right.$ surface area plots) to establish mean $\left(D_{B}\right)$ and large $\left(D_{m}\right)$ sizes of clasts. The maximum size clasts, observed in several sample plots from selected beach ridge entrenchment features, were also measured to the nearest centimeter.

\section{Results}

5.1. Historical 1964 Farfield Tsunami. The inundations of the 1964 historical tsunami in the Necanicum and Neawanna channels provide comparative measures of flow inundation and resulting sand sheet deposition in the Seaside locality. 


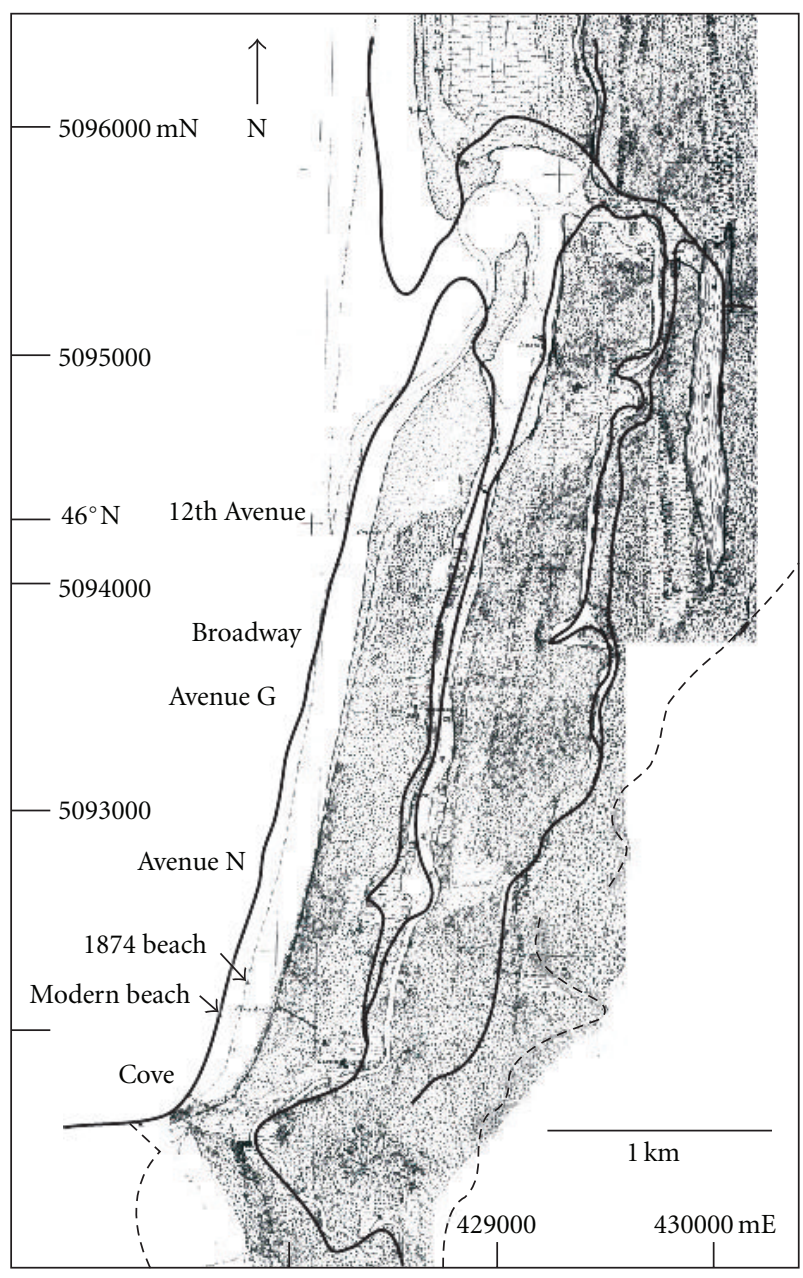

- - - Foot of hillslope (7 m NGVD88)

- Modern shoreline

Figure 7: Early historic map of the Seaside area from Coast of Oregon Survey (1874) with overlays of modern beach and bay shorelines (bold lines). Map overlays are based on visual best-fit scaling of Necanicum River shorelines. The beach shorelines show relatively little change since 1874 . However, forest cover patterns on the Necanicum Bay spit suggest that substantial shoreline changes occurred in the bay mouth prior to the 1874 survey. The seawardmost beach ridges show apparent decreases in forest cover north of Avenue $\mathrm{N}$ and north of 12th Avenue, suggesting recent northward extensions of the spit prior to 1874 . The historic 1874 map base is from U.S. Coastal Survey [10].

Both the 1964 tsunami highwater flood lines and the limits of sand deposition in Seaside are documented in historic photographs and by eye-witness accounts (Figure 5) [5, 6]. The historical tsunami sand layers have been verified for presence, preservation potential, and thickness in the intertidal wetlands of the Necanicum and Neawanna valleys (Figure 5). The 1964 tsunami (4-5 m runup) produced substantial sand layers $(1-10 \mathrm{~cm}$ thick) in the lower valley reaches that were characterized by high-velocity tsunami flow and abundant fine-sand supply in shallow channel bottoms.
TABLE 3: Reported equations for calculating flow tractive forces from bed shear stress and critical entrainment shear stress.

\begin{tabular}{lc}
\hline Sources & Bottom shear stress \\
\hline Modified DuBoys & $T_{c}=\rho g d S$ \\
Shields* Miller et al. [23] & $T_{c}=0.045\left(\rho_{s}-\rho\right) g D_{m}$ \\
Komar [24, 25] & $T_{c}=0.045\left(\rho_{s}-\rho\right) g D_{B}^{0.6} D_{m}{ }^{0.4}$ \\
\hline
\end{tabular}

The modified DuBoys equation for flowing water in broad shallow channels relates its bed shear stress $T_{c}\left(\mathrm{~N} \mathrm{~m}^{-2}\right)$ to the fluid density $\rho\left(1000 \mathrm{~kg} \mathrm{~m}^{-3}\right)$, gravitational acceleration $g\left(9.8 \mathrm{~m} \mathrm{~s}^{-2}\right)$, flow depth $d(m)$, and flow slope $S$ (rise:run). The Shields entrainment relations, as modified by Miller [23], and Komar [24, 25], relate bottom shear stress to clast transport, where $T_{c}$ is critical shear stress $\left(\right.$ dyne $\left.\mathrm{cm}^{-2}\right), \rho_{s}$ is grain density $\left(\mathrm{g} \mathrm{cm}^{-3}\right), \rho_{s}$ is fluid density $\left(\mathrm{g} \mathrm{cm}^{-3}\right), D_{m}$ is grain intermediate diameter of the largest clast transported $(\mathrm{cm})$, and $D_{50}$ is bed mean grain size $(\mathrm{cm})$.

The 1964 sand layers diminish in continuity and thickness with distance upstream in the narrow interridge valleys. Preserved tsunami sand layers reach only 50-60 percent of the inundation distance in the Necanicum valley and only 20-30 percent of the inundation distance in Neawanna valley (Figure 5) [6]. The lack of tsunami sand deposition in the upper valley reaches corresponds to decreased tsunami flow velocity and decreased sand supply in the gravelly channel bottoms. Based on the historical 1964 tsunami sand sheet distributions we expect a strong correspondence between paleotsunami flow and sand sheet deposition on the landward slopes of the overtopped beach ridges. We expect diminished sand sheet representation of paleotsunami inundation in the back-edge wetlands that (1) ramp-up against the beach plain hill slope, and (2) are distant from sand sources in the abandoned beach ridges and tidal channels.

5.2. Ridge Overtopping Areas. In this paper, the stratigraphic evidence of paleotsunami inundation by cobble ridge overtopping is presented for six areas (Areas 1-6) within the Seaside beach ridge plain (Figure 2). The representative areas are selected on the bases of (1) multiple paleotsunami layers located landward of stable ridges, (2) signs of scour into some the cobble ridges, and (3) wide ranges in ridge elevations and landward slopes. The overtopping areas are discussed below in a clock-wise order, starting with the Palmrose Bog (Area 1) at the southeast corner of the beach plain. Following the presentation of overtopping evidence, we address minimum overtopping heights and flow stresses in Areas 1, 3, 5, and 6.

5.3. Overtopping Area 1. Four representative cores from the selected freshwater bog sites near the Palmrose midden (Figure 2) contain 1 to 2 thin sand layers each (Figure 6). The sand layers range from 0.1 to $3 \mathrm{~cm}$ in thickness, and grade upwards into silt and organic debris. The uppermost paleotsunami sand layer is associated with an apparent subsidence contact, corresponding to the AD 1700 Cascadia rupture, as dated by the buried peat (515-688 yr BP) at site 832. The underlying peat predates the coseismic subsidence and tsunami event. A deeper paleotsunami layer at $1-1.5 \mathrm{~m}$ depth below the AD 1700 subsidence horizon in sites D2 and 730 could correlate to paleotsunami event \#3 at about $1.3 \mathrm{ka}$ 

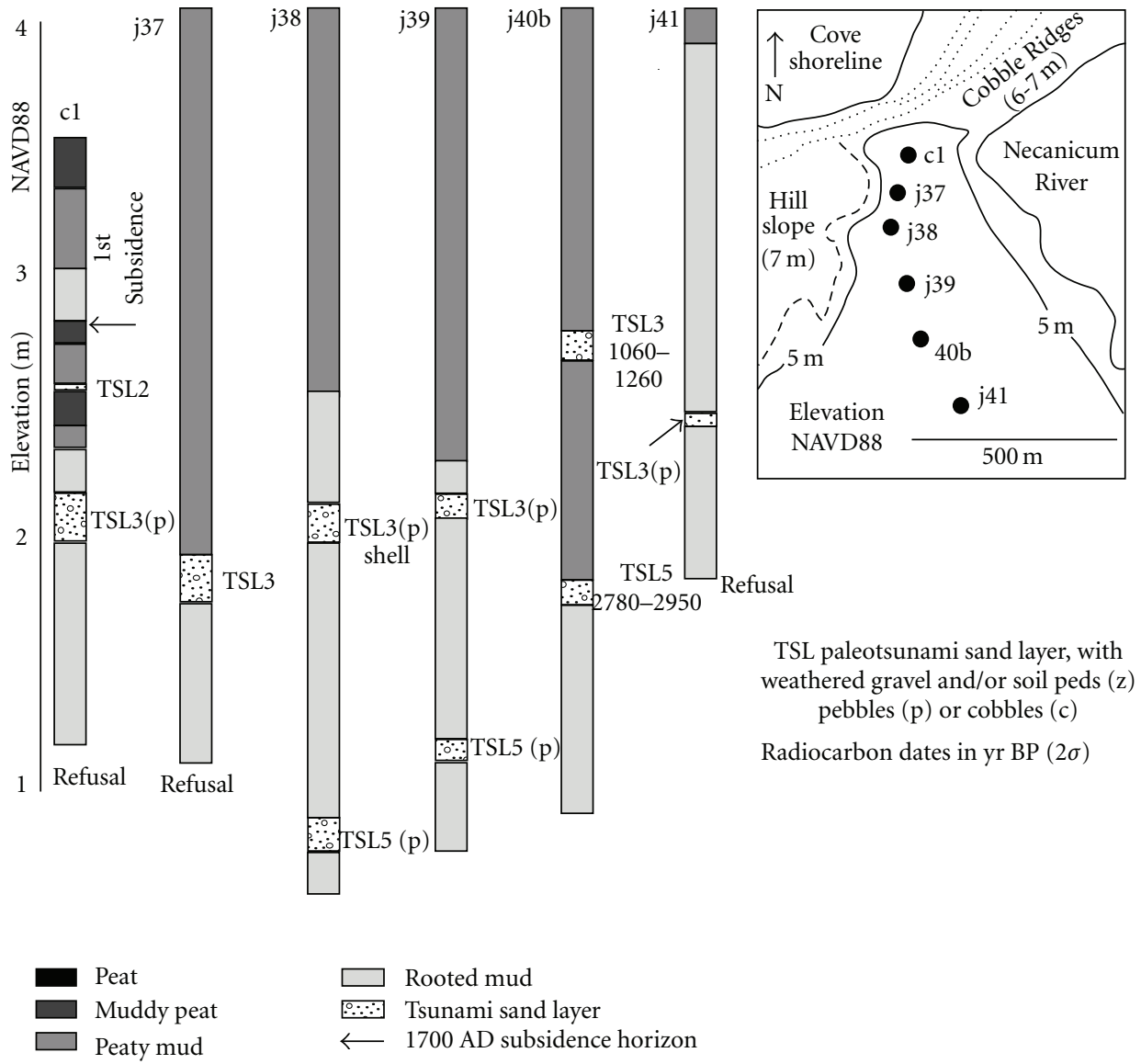

Figure 8: Core logs and inset site map from the Cove wetlands (overtopping Area 2). See Figure 2 for area location and Table 1 for radiocarbon data.

(Table 2). This age is consistent with a dated paleotsunami layer (1094-1409yr BP) at a similar depth (1.5 m) in nearby site NW2 (Figure 3).

The sand source mineralogy of the paleotsunami sand layers, ranging from 10 to 40 percent beach sand, reflects both fluvial and beach sand supply $[3,9]$. The mixing of beach and fluvial sand sources in the Palmrose paleotsunami deposits could occur from surge inundation and sediment recharging in the Necanicum River channel, as recorded at site j70 (Figure 6). Paleotsunami surges transporting river sand could reach site $j 70$ by propagating up the Necanicum channel from the Necanicum Bay mouth (Figures 2 and 4). A direct test of seawardmost beach ridge overtopping required additional investigations of wetland localities that are situated south and/or seaward of any Necanicum channel influence (see Sections 5.5 and 5.6).

5.4. Historical Bay Mouth Migrations. Intact wetlands occur directly landward of the seawardmost beach ridges in two localities of the southern Seaside beach plain, including the Cove and Avenue N, corresponding to overtopping Areas 2 and 3, respectively, (Figure 2). The earliest detailed coastal survey of the Seaside beach plain (Figure 7) shows both the beach ridge morphology at the Cove and the course of the nearby Necanicum River to be largely unchanged since AD 1874. Net beach accretion has preserved the earliest historical beach ridge morphology in the south Seaside beach plain. By comparison, substantial changes in shoreline position have occurred at the mouth of the Necanicum Bay since early historical time (1874), and probably since the last Cascadia rupture at $\mathrm{AD} 1700$ [16].

5.5. Overtopping Area 2. Six cores are shown in a west-to-east transect to establish paleotsunami overtopping of the $7 \mathrm{~m}$ NAVD88 Cove beach ridge (Figure 8). Attempted coring in wetland sites immediately adjacent to the Cove beach ridges met with penetration refusal due to the presence of large clasts at shallow depths (1.0-1.5 m deep). Cores, taken at sites located more than $100 \mathrm{~m}$ distance from the Cove beach ridges, yielded deeper stratigraphic sections, including 2-3 anomalous sand layers. The quartz-rich beach-source sand from the anomalous sand layers generally ranges from 180 to $350 \mu \mathrm{m}$ in size. The shallowest sand layer $(\sim 1 \mathrm{~cm}$ thick $)$ in the most proximal site (c1) occurs below the youngest preserved subsidence horizon, thus predating the AD 1700 Cascadia rupture (Table 1). This shallowest sand layer, tentatively attributed to paleotsunami event \#2, pinches out within a short distance $(200 \mathrm{~m})$ landward from the Cove beach ridges. 


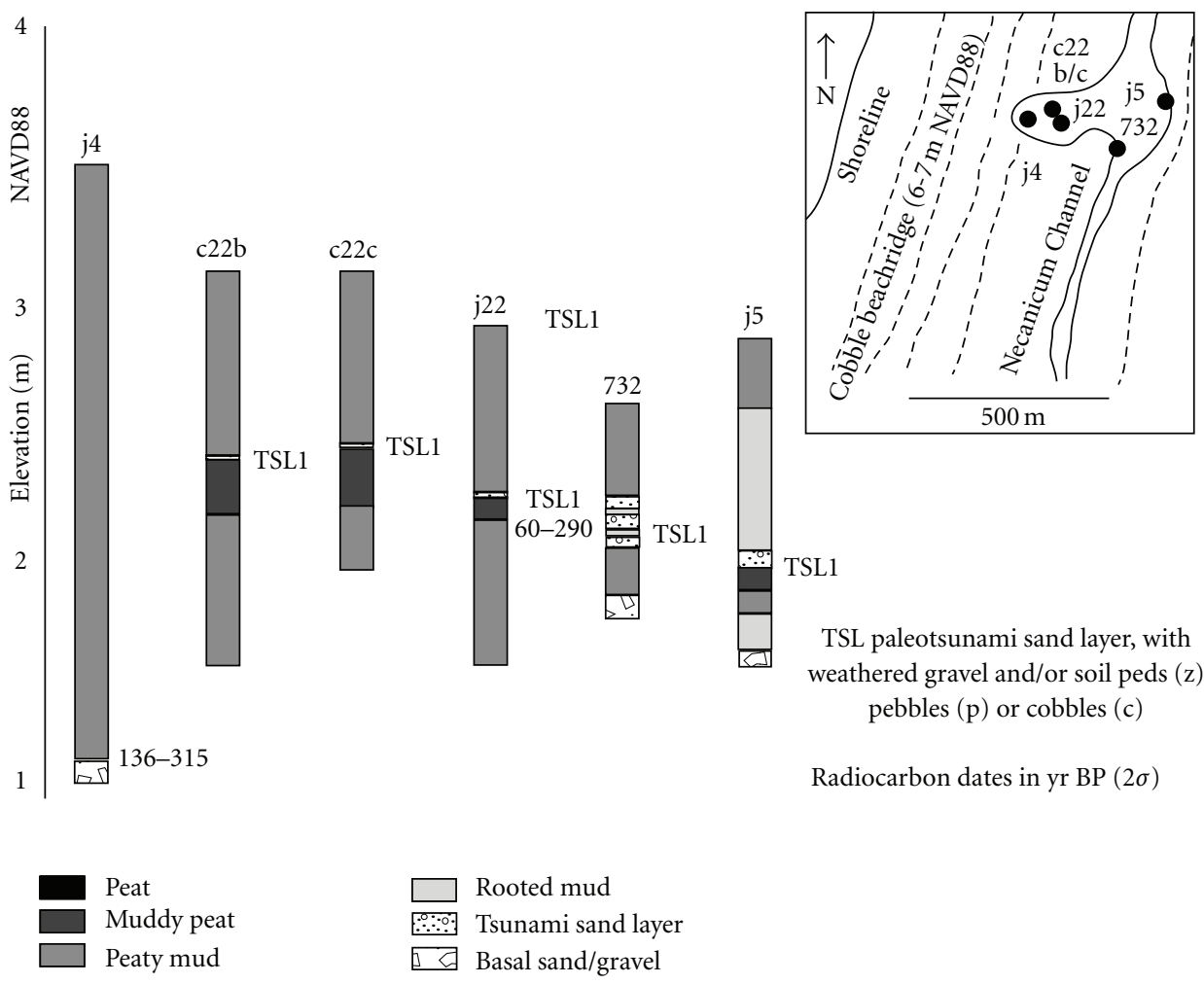

FIGURE 9: Core logs and inset site map from the Avenue $\mathrm{N}$ wetlands (overtopping Area 3). See Figure 2 for area location and see Table 1 for radiocarbon data.
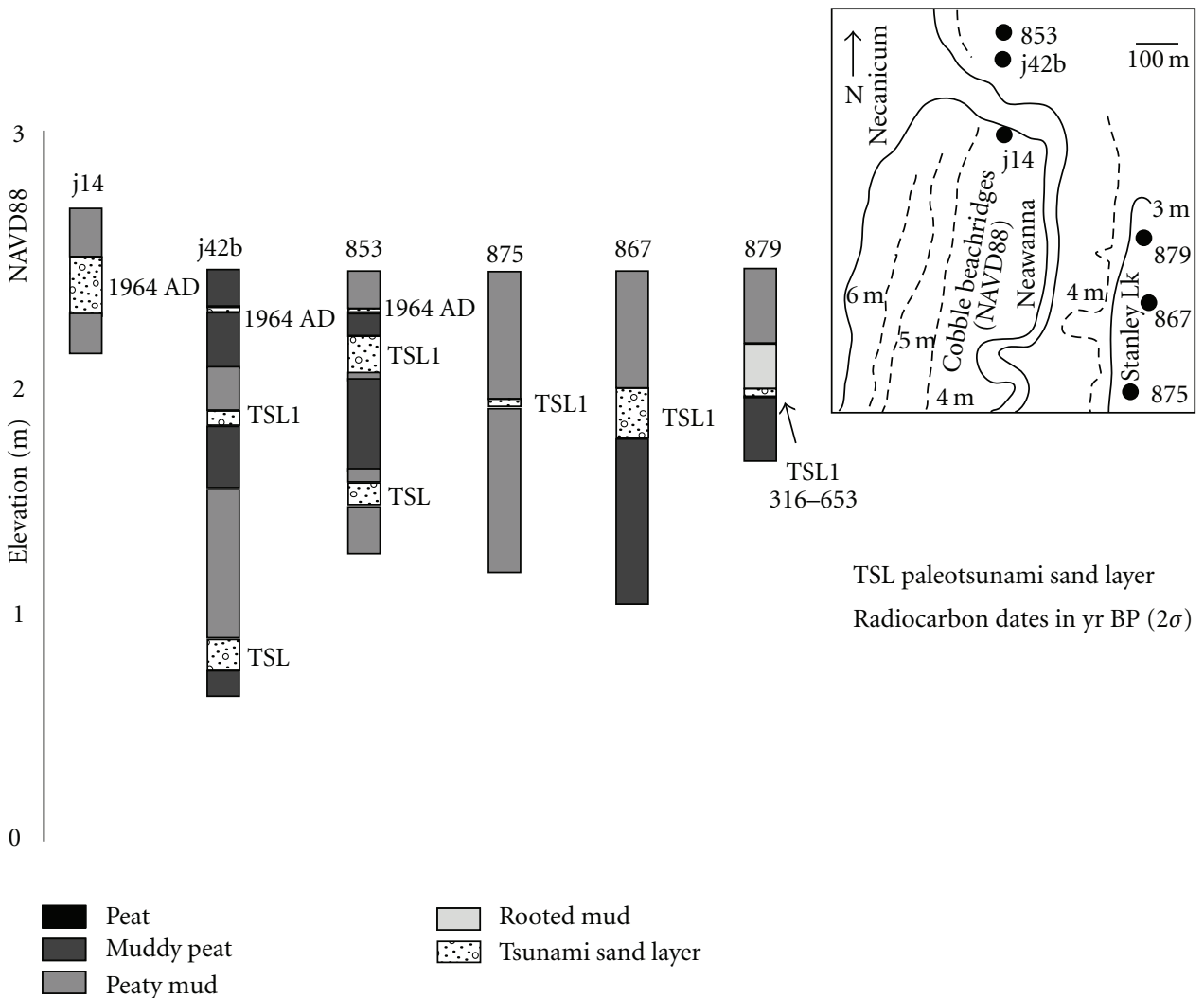

Tsunami sand layer

Figure 10: Core logs and inset site map from the Northeast Necanicum and Stanley Lake wetlands (overtopping Area 4). See Figure 2 for area location and see Table 1 for radiocarbon data. Cobble ridge crests (dotted lines) are shown with elevation contours. 
TAвLe 4: Paleotsunami clast sizes from the Seaside beach plain.

\begin{tabular}{|c|c|c|c|c|c|c|}
\hline Site & Event & Transport condition & Depth $(\mathrm{m})$ & $\begin{array}{l}\text { Bed clast size } \\
D_{B} \pm 1 \sigma \mathrm{cm}\end{array}$ & $\begin{array}{c}\text { Largest clast size } \\
D_{m}(\mathrm{~cm})\end{array}$ & $\begin{array}{l}\text { Maximum clast } \\
\text { size } D_{\text {max }}(\mathrm{cm})\end{array}$ \\
\hline 867 & $\# 1$ & Deposited & 0.5 & 0.02 & 0.02 & \\
\hline 3rd Ave & $\# 3,5$ ? & Eroded & Ridge & $9.1 \pm 3.8$ & 13.6 & 26 \\
\hline 712 & $\# 1$ & Deposited & 0.3 & 0.02 & 0.02 & \\
\hline 822 & $\# 2$ & Deposited & 0.9 & 0.02 & 5.2 & 6.0 \\
\hline AveK & $\# 3,5$ ? & Eroded & Ridge & $8.1 \pm 5.3$ & 19 & 32 \\
\hline $\mathrm{j} 44$ & \#1 & Deposited & 1.2 & 0.02 & 12.4 & 20 \\
\hline j70 & \#1 & Deposited & 0.7 & 0.02 & $2.0^{*}$ & \\
\hline AveN & $\# 3,5$ ? & Eroded & Ridge & $10 \pm 5$ & 20 & 30 \\
\hline 832 & \#1 & Deposited & 1.1 & 0.02 & 0.02 & \\
\hline $\mathrm{j} 38$ & $\# 3$ & Deposited & 2.0 & 0.02 & $2.0^{*}$ & - \\
\hline j38 & $\# 5$ & Deposited & 3.2 & 0.02 & $2.0^{*}$ & - \\
\hline j41 & $\# 3$ & Deposited & 1.5 & 0.02 & $2.0^{*}$ & - \\
\hline
\end{tabular}

Paleotsunami events (\#) are presented in Table 2.

Bed grain size includes mean $\left(D_{B}\right)$ with \pm 1 std $\operatorname{Dev}(\mathrm{cm})$ from sample plot.

Largest clast sizes $\left(D_{m}\right)$ are from the sample plots $\left(0.25 \mathrm{~m}^{2}\right)$ analyzed for each site.

Maximum clast sizes $\left(D_{\max }\right)$ are from largest clast size observed in several sample plots from each site.

${ }^{*}$ Deposited pebble sizes (sites j70, j38, j41) are taken from cores (diameter $2.5 \mathrm{~cm}$ ) thereby limiting large clast size to less than $2.5 \mathrm{~cm}$ diameter.

Core sites 867, 712, 822, 832 are reported elsewhere [4], as are core sites j44, j70, j38, j41 [6]. Entrenchment sites 3rd Ave, AveK, and AveN, are first identified in this paper.

Eroded cobble sizes are taken from breached cobble ridge crests at 3rd Ave, AveK, and southwest of AveN. Deposited cobble sizes are taken from cutbank exposures at sites 822 and j44. See core site locations in Figures 6-14.

TABLE 5: Bed shear stress estimated for paleotsunami flow down beach ridge slopes at selected overtopping localities.

\begin{tabular}{|c|c|c|c|c|}
\hline Locality & $\begin{array}{c}\text { Flow depth } \\
(\mathrm{m})\end{array}$ & Slope gradient & $\begin{array}{l}\text { Shear stress } \\
\quad\left(\mathrm{N} \mathrm{m}^{-2}\right)\end{array}$ & $\begin{array}{l}\text { Shear stress } \\
\left(\text { dyne } \mathrm{cm}^{-2}\right)\end{array}$ \\
\hline \multicolumn{5}{|l|}{ Area 3} \\
\hline Ave N & 0.5 & 0.017 & 83 & 830 \\
\hline Ave N & 1.0 & 0.017 & 167 & 1670 \\
\hline Ave $\mathrm{N}$ & 1.5 & 0.017 & 250 & 2500 \\
\hline Ave $\mathrm{N}$ & 2.0 & 0.017 & 333 & 3330 \\
\hline \multicolumn{5}{|l|}{ Area 5} \\
\hline 3rd Ave & 0.5 & 0.013 & 64 & 640 \\
\hline 3rd Ave & 1.0 & 0.013 & 127 & 1270 \\
\hline 3rd Ave & 1.5 & 0.013 & 191 & 1910 \\
\hline 3rd Ave & 2.0 & 0.013 & 255 & 2550 \\
\hline \multicolumn{5}{|l|}{ Area 6} \\
\hline Ave K & 0.5 & 0.012 & 49 & 490 \\
\hline Ave K & 1.0 & 0.012 & 98 & 980 \\
\hline Ave K & 1.5 & 0.012 & 147 & 1470 \\
\hline Ave K & 2.0 & 0.012 & 196 & 1960 \\
\hline \multicolumn{5}{|l|}{ Area 1} \\
\hline Palmrose & 0.5 & 0.002 & 10 & 100 \\
\hline Palmrose & 1.0 & 0.002 & 20 & 200 \\
\hline Palmrose & 1.5 & 0.002 & 29 & 290 \\
\hline Palmrose & 2.0 & 0.002 & 39 & 390 \\
\hline
\end{tabular}

Tractive forces or bed shear stresses (Newtons $\mathrm{m}^{-3}$ and dyne $\mathrm{cm}^{-3}$ ) are calculated for four paleotsunami overtopping localities using a range of flow depths (1-2 $\mathrm{m}$ depth) and measured slopes ( $\mathrm{m}: \mathrm{m}$ gradients) in the modified DuBoys equation (Table 3 ). Ground surface gradients at the paleotsunami overtopping localities are shown in Figures 16 and 17. Larger flow depths $(2.0 \mathrm{~m})$ could represent paleotsunami events \#3 and \#5. Small flow depths $(0.5-1.0 \mathrm{~m})$ could represent paleotsunami event \#1 at AD 1700. 
TABLE 6: Critical shear stress calculated from transported clast sizes.

\begin{tabular}{|c|c|c|c|c|c|}
\hline Site & Event & Setting & $\begin{array}{l}\text { Mean clast shear } \\
\text { stress dyne } \mathrm{cm}^{-2}\end{array}$ & $\begin{array}{l}\text { Large clast shear } \\
\text { stress dyne } \mathrm{cm}^{-2}\end{array}$ & $\begin{array}{c}\text { Maximum clast shear } \\
\text { stress dyne } \mathrm{cm}^{-2}\end{array}$ \\
\hline 867 & $\# 1$ & Deposit & $10(\mathrm{~s})$ & - & - \\
\hline $3 \mathrm{rd} \mathrm{A}$ & $\# 3,5$ ? & Eroded & $740(\mathrm{c})$ & $870(\mathrm{c})$ & $1130(b)$ \\
\hline 712 & $\# 1$ & Deposit & $10(\mathrm{~s})$ & - & - \\
\hline 822 & $\# 2$ & Deposit & $10(\mathrm{~s})$ & $15(\mathrm{c})$ & $16(c)$ \\
\hline AveK & $\# 3,5$ ? & Eroded & $660(\mathrm{c})$ & $930(\mathrm{c})$ & $1140(\mathrm{~b})$ \\
\hline j44 & $\# 1$ & Deposit & $10(\mathrm{~s})$ & $21(\mathrm{c})$ & $26(\mathrm{c})$ \\
\hline j70 & $\# 1$ & Deposit & $10(\mathrm{~s})$ & $10(\mathrm{p})$ & - \\
\hline AveN & $\# 3,5$ ? & Eroded & $820(\mathrm{c})$ & $1080(\mathrm{c})$ & $1260(\mathrm{~b})$ \\
\hline 832 & $\# 1$ & Deposit & $10(\mathrm{~s})$ & - & - \\
\hline j38 & $\# 3$ & Deposit & - & $10(\mathrm{p})$ & - \\
\hline j38 & $\# 5$ & Deposit & - & $10(\mathrm{p})$ & - \\
\hline $\mathrm{j} 41$ & $\# 3$ & Deposit & - & $10(\mathrm{p})$ & - \\
\hline j41 & $\# 3$ & Deposit & 一 & $10(\mathrm{p})$ & - \\
\hline
\end{tabular}

Estimated ages of paleotsunami events (\#) are shown in Table 2. Critical entrainment is evaluated for clasts in paleotsunami deposits (Deposit) and for representative clasts dislodged from cobble beach ridges (Eroded) as shown in Table 4. Critical entrainment shear stresses $\left(\right.$ dyne $\left.\mathrm{cm}^{-2}\right)$ are estimated for sandsheet-flow (s) and pebbles (p) in sand-sheet-flow $\left(\sim 10\right.$ dyne $\left.\mathrm{cm}^{-2}\right)$, cobbles (c) in sand-sheet-flow $\left(\sim 15-26\right.$ dyne $\left.\mathrm{cm}^{-2}\right)$, and cobbles and boulders dislodged

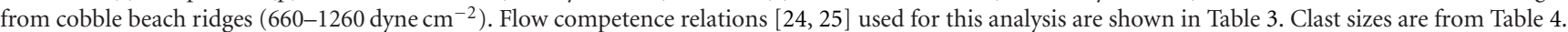

More distal core sites in the Cove wetlands track the two deepest paleotsunami sand-sheets, between 1.5 and $3 \mathrm{~m}$ depth, to $750 \mathrm{~m}$ distance landward of the Cove beach ridges (Figure 8) [6]. Penetration refusal occurred at about $3 \mathrm{~m}$ depth in the most proximal core sites $(\mathrm{c} 1, \mathrm{j} 37)$ due to large clasts (cobble or boulder size). Pebbles (1-2 cm diameter) were recovered in the $2.5 \mathrm{~cm}$ diameter gouge core from both of the lower sand-sheets at sites j38, j39, and j41. Marine shell fragments were recovered in the paleotsunami sand-sheet at $199-201 \mathrm{~cm}$ depth in core site $j 38$.

The two deepest sand-sheets from the Cove wetlands (Figure 8) are dated by radiocarbon at 1060-1260 and 27802950 cal yr BP (Table 1). These two sand-sheets, produced by the \#3 paleotsunami event $(\sim 1.3 \mathrm{ka})$ and the \#5 paleotsunami event ( $2.6 \mathrm{ka}$ ) (Table 2$)$, represent the highest paleotsunami runups recorded in the Seaside beach plain. The furthest landward extents of these two sand-sheets in the Cove wetlands were not pursued during the Seaside Tsunami Pilot Study [6]. They likely extend beyond $1.0 \mathrm{~km}$ in distance from the Cove Beach ridges, thus merging with potential shoreparallel inundation up the Necanicum channel (Figure 4). Pebble transport and deposition in paleotsunami sand-sheets at sites $\mathrm{c1}, \mathrm{j} 38, \mathrm{j} 39$, and $\mathrm{j} 41$ argue for sustained high-velocity flow over the back-ridge plain at the Cove.

5.6. Overtopping Area 3. To further test for the event \#1 paleotsunami runup height, some additional cores were taken in proximal wetlands at Avenue N (Figure 2). The Avenue $\mathrm{N}$ wetlands occur in a shallow entrenchment feature or gully, that is, oriented somewhat oblique to the beach ridges. The gully feature truncates two minor ridge crests at its seaward margin (Figure 9), therefore it postdates the shoreline progradation. The paleotsunami gully or coulee feature is interpreted to have originated from localized paleotsunami erosion on the landward slope of the grouped cobble ridges, as discussed in greater detail in following sections. The intact seawardmost cobble ridges reach about $6 \mathrm{~m}$ elevation at the Avenue $\mathrm{N}$ in Overtopping Area 3.

Peaty mud sections cored in the Avenue $\mathrm{N}$ wetlands (Figure 9) contain a single subsidence event and an associated paleotsunami sand layer (grain size $180-350 \mu \mathrm{m}$ ). The subsided peat surface is radiocarbon dated at 60 $290 \mathrm{cal} \mathrm{yr} \mathrm{BP}$ at core site j22 (Table 1). The shallow subsidence horizon and paleotsunami layer are interpreted to record the last Cascadia rupture and paleotsunami event \#1 at AD 1700 (Table 2). The development of the pre-AD 1700 peaty horizon within the Avenue N paleotsunami gully post-dates the original downcutting of the cobble ridges, by previous paleotsunamis, likely including event \#3 (see Section 5.5).

The AD 1700 paleotsunami apparently propagated up the Necanicum interridge valley from the Necanicum Bay mouth as recorded by a substantial paleotsunami layer $(\sim$ $20 \mathrm{~cm}$ thick) of mixed beach and river sand mineralogy at site 732 (Figure 9) [4]. Three sand layers, separated by river/bay mud laminae in the Necanicum bank (site 732), could indicate multiple surges from the AD 1700 tsunami up the Necanicum channel from the bay mouth.

A young date for a twig in the basal mud at core site j4 (136-315yr BP) could indicate scour by the $\mathrm{AD}$ 1700 paleotsunami at the head of the Avenue $\mathrm{N}$ wetlands (Figure 9). If the $\mathrm{AD} 1700$ paleotsunami did overtop the seawardmost beach ridges at $\sim 6 \mathrm{~m}$ elevation near Avenue $\mathrm{N}$, then the resulting flow left only thin sand deposits at sites j22, c22b, and c22c. The interpreted predominant flow from the $\mathrm{AD} 1700$ paleotsunami was directed shore-parallel up the Necanicum channel from the Necanicum Bay mouth (Figure 4). 

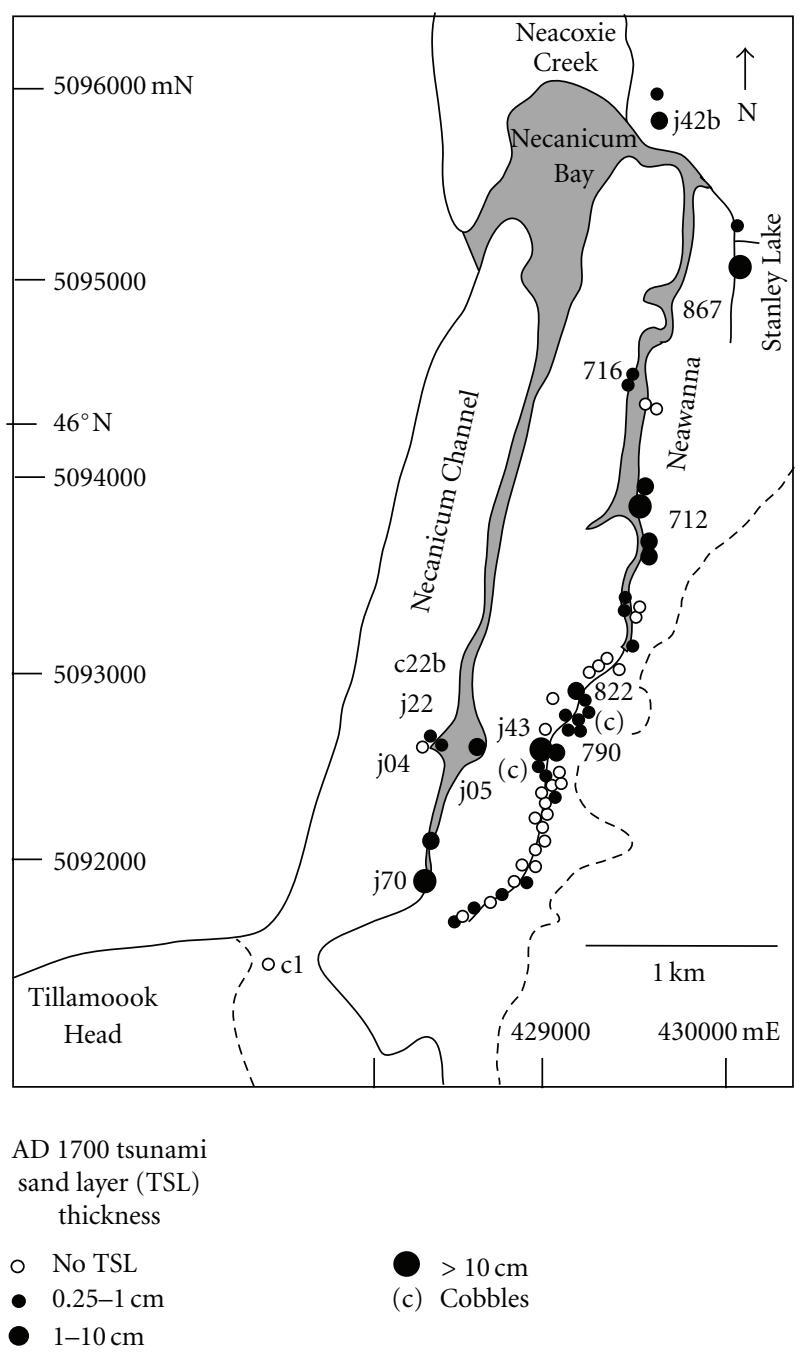

FIGURE 11: Map of AD 1700 paleotsunami sand layers, as confirmed by association with a coseismic subsidence contact and/or radiocarbon dating. Core site logs and dates are compiled elsewhere $[4,6]$.

5.7. Overtopping Area 4. Wetlands near the confluence of the Neawanna and Necanicum channels at Area 4 (Figure 2), record the historical (1964) tsunami sand-sheet (Figure 5) as well as paleotsunami from the Cascadia AD 1700 rupture (Figure 10). The geometry of the Necanicum Bay mouth at the time of the $\mathrm{AD} 1700$ event is not well constrained due to apparent northward migration of the bay mouth in earliest historical time (Figure 7). Tsunami inundation from the Necanicum Bay mouth could have propagated northwards to the northeast bay wetlands through a Necanicum-Neawanna channel, as occurred during the historical 1964 tsunami in Seaside $[1,5]$.

Alternatively, the $\mathrm{AD} 1700$ inundation could have crossed from southwest to northeast over the low gravel ridges $(\sim$ $5 \mathrm{~m}$ elevation) that separate the Necanicum and Neawanna channels (Figure 4). An overtopping of the intervening cobble ridges is supported by the occurrence of a prominent $\mathrm{AD} 1700$ sand-sheet $(23 \mathrm{~cm}$ thick) at site 867 in Stanley Lake on the landward side of the Neawanna channel (Figure 10).

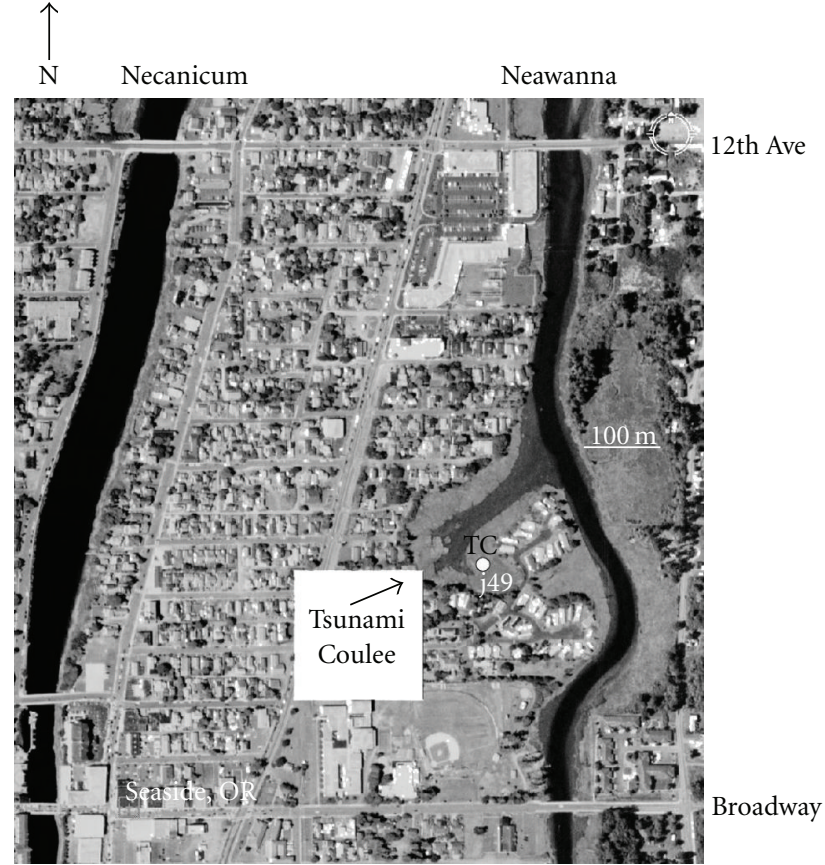

Figure 12: Google Earth image of a Seaside Neighborhood showing an anomalous entrenchment feature, termed a tsunami coulee (bold), located on the west side of the Neawanna tidal channel (see Figures 2 and 14 for location in Seaside). The tsunami coulee $(\sim 150 \mathrm{~m}$ in length) cuts two cobble ridges that are aligned northto-south. The tsunami coulee is interpreted to represent headward erosion from paleotsunami flow(s) trending northeast over the cobble ridges ( $\sim 5 \mathrm{~m}$ elevation).

The AD 1700 sand-sheet thins abruptly to the north (site 879 ) and south (site 875) of a slight saddle, or breach, in the low cobble ridge ( $4 \mathrm{~m}$ elevation) that separates the Neawanna and Stanley Lake wetlands near site 867.

5.8. AD 1700 Tsunami Sand-Sheet Distribution. Localized distributions of $\mathrm{AD} 1700$ sand layers at the back-edge of the Seaside beach plain have confounded earlier attempts at establishing flooding mechanisms [3-5]. Additional coring work confirmed the localized sand-sheet deposition [6], and raised the possibility of shallow channelized flow through passes in the cobble ridges. We summarize the localized sand-sheet deposition from the AD 1700 paleotsunami in the Neawanna wetlands to target potential areas of ridge overtopping.

The preserved $\mathrm{AD} 1700$ subsidence sites, as recorded in the Seaside beach plain wetlands (Figure 11), are derived from the first subsidence horizons (buried peats) observed downcore $[4,6]$. The absence, presence, and thickness of paleotsunami sand layers associated with the $\mathrm{AD} 1700$ subsidence horizon (buried peat) are shown for each site. Other possible AD 1700 paleotsunami deposits [6] that are not confirmed by a corresponding subsidence horizon or by radiocarbon dating are not included in Figure 12.

Confirmed AD 1700 paleotsunami sand layers extend up the Necanicum channel wetlands to site j70 (Figure 11). 


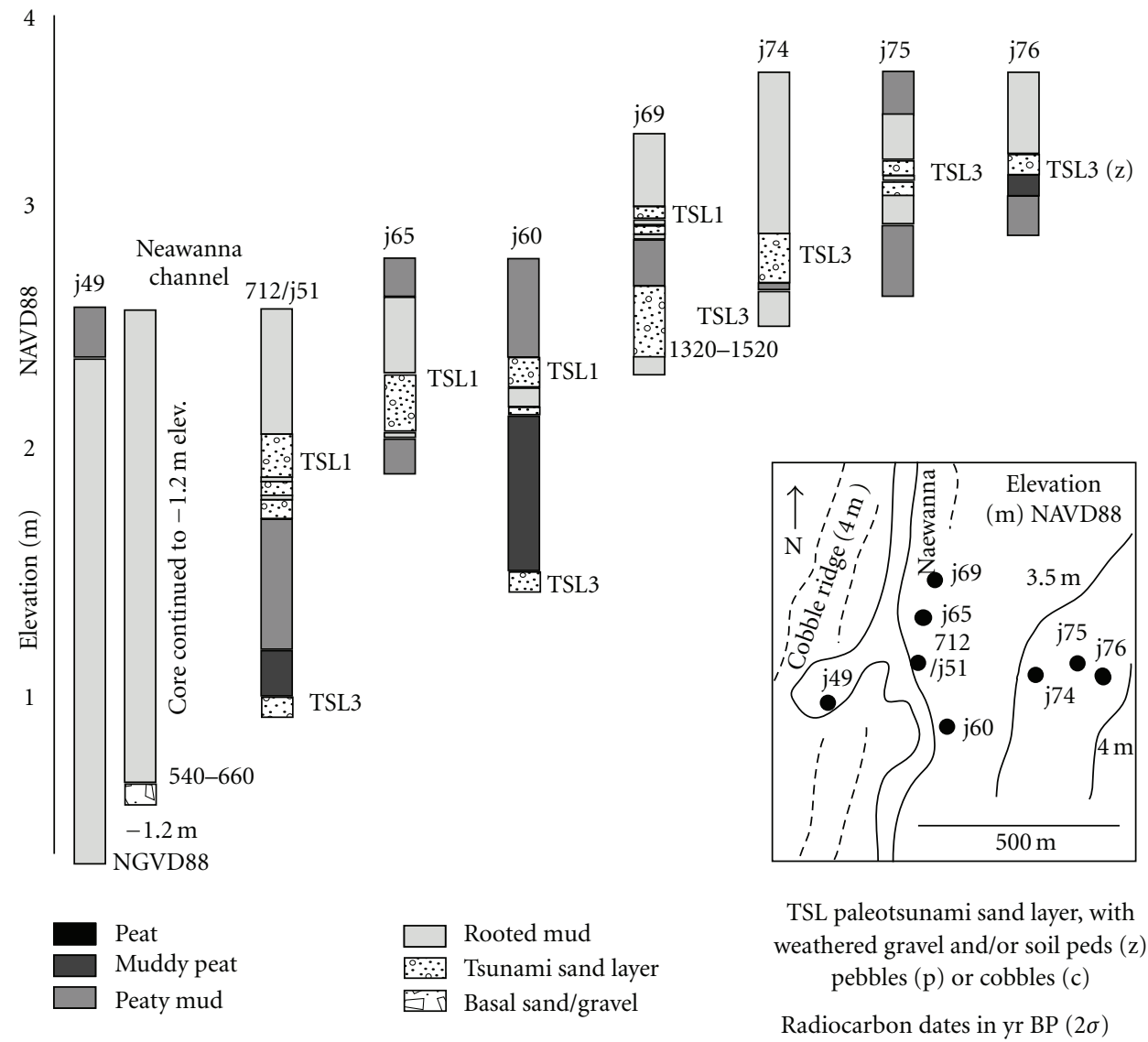

Figure 13: Core logs and inset site map from the 3rd Avenue wetlands, overtopping Area 5. See Figure 2 for area location and see Table 1 for radiocarbon data.

No preserved AD 1700 subsidence records are found in the north Necanicum channel wetlands. The recent northward migration of the tidal inlet (Figure 7) appears to have initiated at a terminated seawardmost beach ridge mapped in $\mathrm{AD} 1874$ at a distance of about $2.0 \mathrm{~km}$ south of the present tidal inlet. That position is consistent with the termination of older cobble beach ridges at Avenue G (Figure 2) and with a lack of preserved AD 1700 paleotsunami layers in the central Necanicum interridge valley.

Relatively thick AD 1700 paleotsunami sand layers (20$30 \mathrm{~cm}$ in thickness) occur at sites j43 and 712 in the Neawanna channel wetlands, and at site 867 on the seaward side of Stanley Lake (Figure 11). Interspersed between the Neawanna sites of thick AD 1700 paleotsunami deposits are sites of thin AD 1700 sand layers or apparent absences of the AD 1700 paleotsunami sand layer. Such variable presence and thickness of the AD 1700 sand layers suggest localized substantial overtopping at Areas 4, 5, and 6 (Figure 2). Overtopping Areas 4, 5, and 6 might have been located landward of the interpreted position of the Necanicum bay mouth at the time of the $\mathrm{AD} 1700$ paleotsunami inundation(s). A broad bay mouth could have focused the AD 1700 paleotsunami inundation directly over the cobble ridges that bound the seaward side of the Neawanna wetlands.
We address the evidence for localized ridge overtopping in two contrasting sites from Areas 5 and 6 below.

5.9. Overtopping Area 5. An anomalous entrenchment feature ( $\sim 100 \mathrm{~m}$ width) on the west bank of the Neawanna channel truncates a cobble beach ridge at 3rd Avenue in Area 5 (Figure 12). The deep gully feature, at least $5 \mathrm{~m}$ depth, is located due seaward of the $30 \mathrm{~cm}$ thick AD 1700 paleotsunami sand layer at site 712 (Figures 11, 12, and 13). This feature is representative of other cobble ridge gullies or headward eroded coulees, such as at Avenue N (Figure 9) in the Seaside beach ridge plain.

The 3rd Avenue paleotsunami gully has been cored to penetration refusal at $415 \mathrm{~cm}$ depth in site j49 (Figure 13). Mud fill in the channel feature overlies a sharp contact with sand/gravel at a depth of $410 \mathrm{~cm}$ depth. A radiocarbon date from a wood fragment in the basal mud $(410 \mathrm{~cm}$ depth) in site $\mathrm{j} 49$ yields an anomalous "young" age (540$660 \mathrm{yr}$ BP) for the $4 \mathrm{~m}$ deep gully (Table 1$)$. Normal sediment accumulation by net sea level rise $(\sim 100 \mathrm{~cm} / 1000 \mathrm{yr})$ should put a $4.0 \mathrm{~m}$ depth horizon at several thousand years in age in the Neawanna wetlands. We attribute the origin of the recent mud backfill to localized paleotsunami scour from the AD 1700 paleotsunami event. 


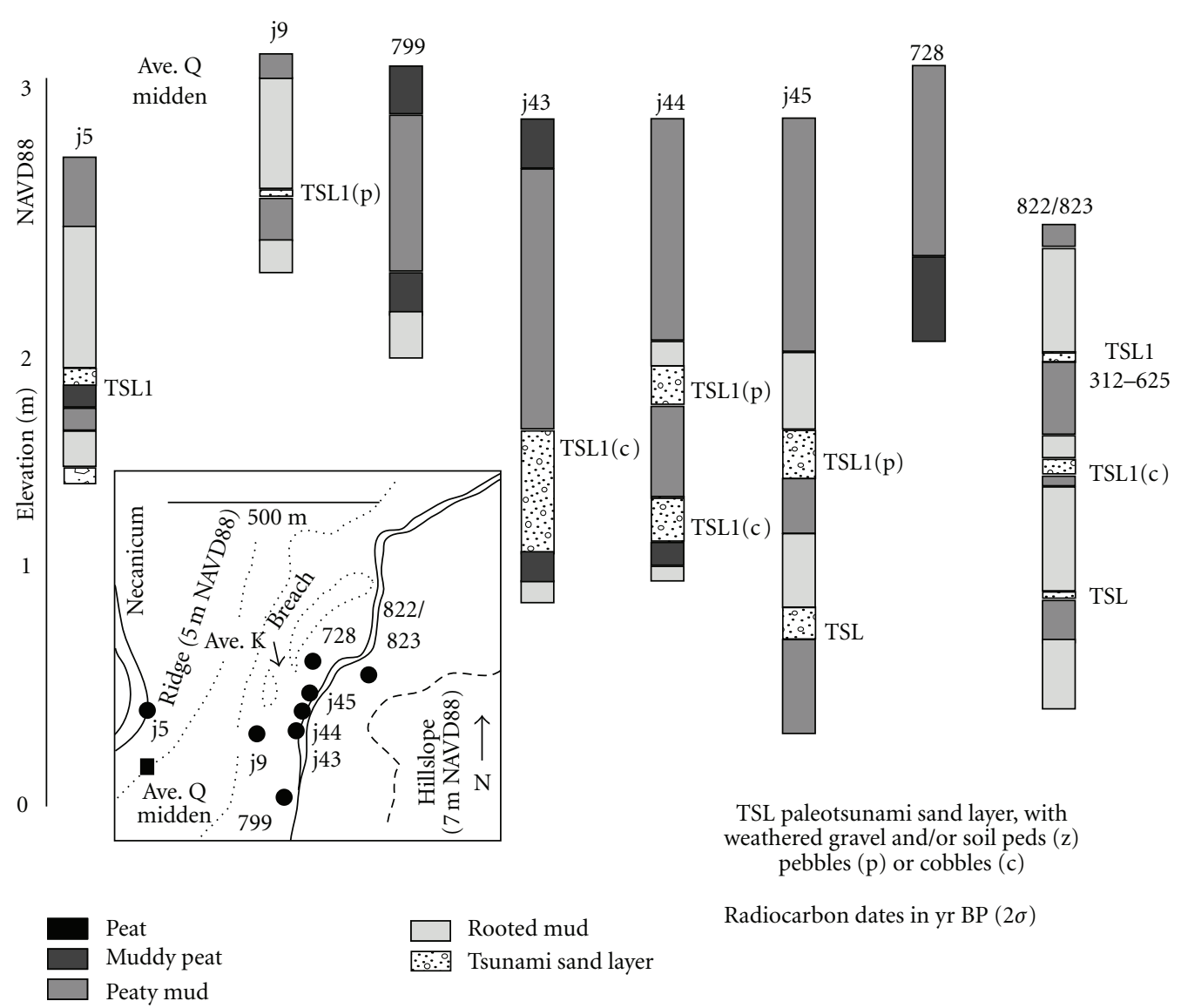

FIgure 14: Core logs and inset site map from the Avenue K wetlands. See Figure 2 for area location and see Table 1 for radiocarbon data.

Core transects originating at site 712 establish broad sand-sheets that extend $\sim 500 \mathrm{~m}$ landward to the back-edge of the beach plain near site j76 (Figure 13). The age of the upper sand-sheet (site $712 / \mathrm{j} 51$ ) is assumed to correlate to the most recent scour of the 3rd Avenue feature at AD 1700. A lower sand-sheet, which extends to the back-edge of the beach plain in Area 5 (Figure 13) correlates to the Cascadia event \#3 paleotsunami, based on a twig date of 1,320$1,520 \mathrm{yr}$ BP at $70 \mathrm{~cm}$ depth in site j69 (Table 1) [6]. This lower sand-sheet is widely recorded along the full length of the back-edge wetlands from site j42b in the north (Figure 10) to sites NW2 and 730 in the south (Figure 3). Weathered gravel and soil concretions, or peds, in the paleotsunami deposit at site j76 indicate that the paleoflow(s) reached and scoured the base of the hillslope colluvium at greater than $5 \mathrm{~m}$ elevation. The hill slope soil debris that is, mixed with tsunami sand represents a tsunami backwash deposit. The headward erosion of the paleotsunami coulee at 3rd Avenue probably correlates to the extensive sand-sheet produced by the very large paleotsunami runup from rupture event \#3 (Table 2).

5.10. Overtopping Area 6. Cutbank exposures of the AD 1700 paleotsunami deposits in the central reaches of the Neawanna wetlands reveal localized presence of pebbles and cobbles (Figure 2). Cobbles are rare in the Neawanna paleotsunami sand layers, but their presence demonstrates substantial shear stress for flows at the back-edge of the beach plain. Cobbles embedded within the $\mathrm{AD} 1700$ sand-sheet (TSL1) at sites j44 and j45 on the west bank of the Newanna channel are associated with localized thickening of the $\mathrm{AD}$ 1700 paleotsunami sand-sheet there (Figure 14).

The AD 1700 paleotsunami sand-sheet thickens (20$45 \mathrm{~cm}$ thick) in the immediate vicinity of paleotsunami cobble emplacements at core sites j43, j44, and j45 (Figure 14). The $\mathrm{AD} 1700$ paleotsunami sand-sheet pinches out to less than $0.25 \mathrm{~cm}$ thickness to the north and south of the embedded cobbles, respectively, at sites 799 and 728 . The breached cobble ridges located landward of the Avenue $\mathrm{K}$ gully could be the source of the paleotsunami cobbles found in the AD 1700 paleotsunami sand layers. The narrow paleotsunami gullies directed high-velocity flow to the marsh sites $\mathrm{j} 43$, j44, and $\mathrm{j} 45$. The Avenue $\mathrm{K}$ overtopping site is representative of the smaller ridge breaches and associated cobble deposits that formed by paleotsunami inundation in the central and southern Neawanna wetlands.

5.11. Clast Entrainment. In an effort to establish paleotsunami flow stresses over the cobble ridges in the Seaside beach plain the paleotsunami deposits and breached cobble 


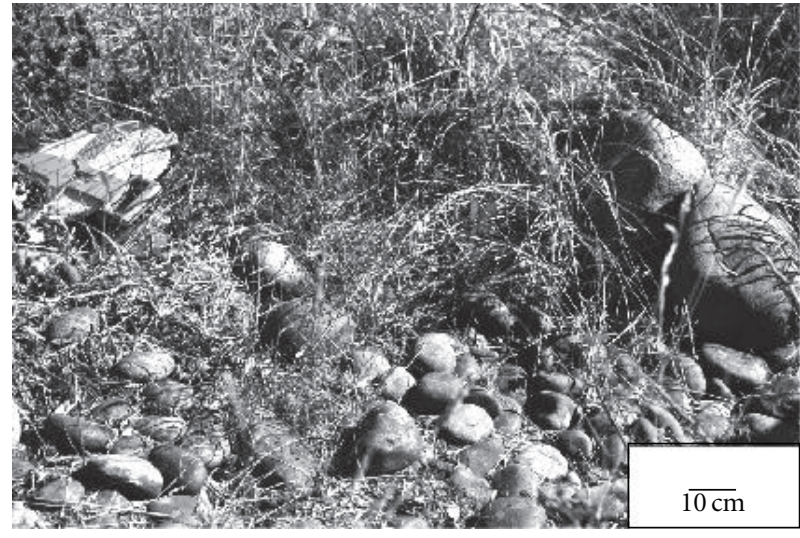

(a)

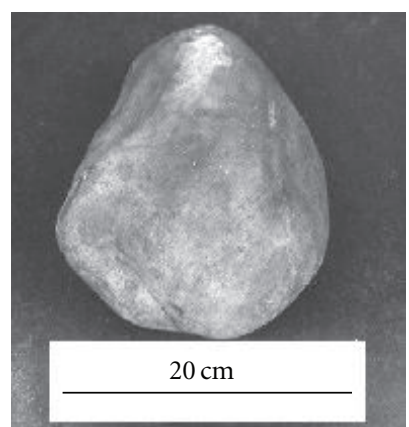

(c)

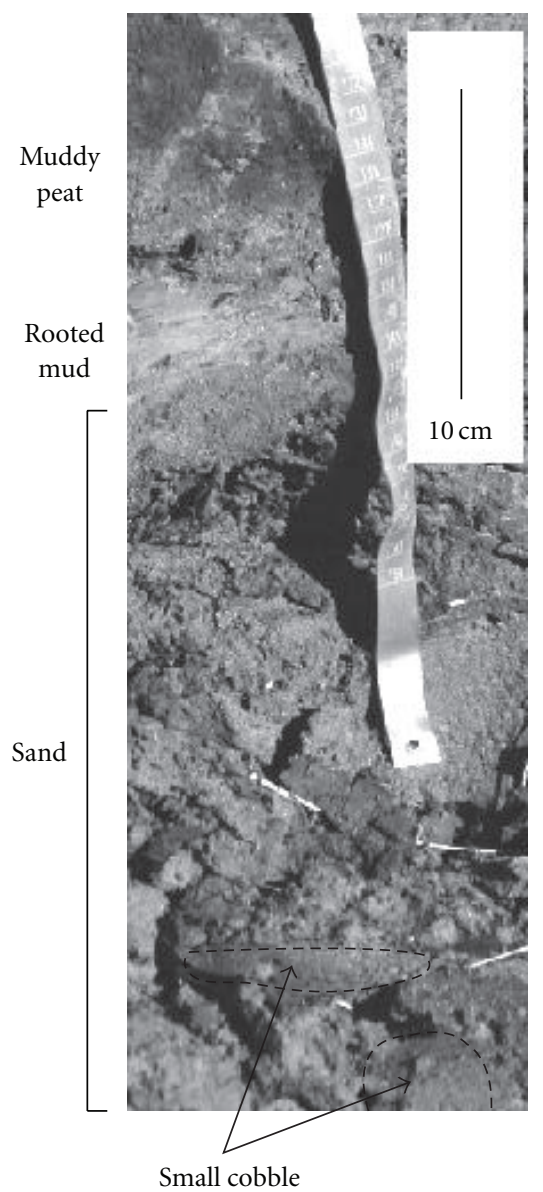

(b)

FIgURE 15: Scaled photograph of cobbles from exposed crest of Avenue K beach ridge (a), (b) Neawanna cutbank section with AD 1700 paleotsunami sand layer and basalt cobbles (adjacent to site j44), and (c) largest tsunami cobble $(20 \mathrm{~cm}$ intermediate axis diameter) in paleomarsh depression in Neawanna cutbank section ( $\sim 160 \mathrm{~cm}$ depth) adjacent to site j44 (see Figure 14 for core site positions).

ridges are analyzed for clast size. Tsunami flow over mixed sand and cobble beach ridges produce remobilized deposits having large clasts embedded in tsunami sand layers [28]. Measurements of pebbles, cobbles, and small boulders are used in later sections of this paper to constrain local conditions of critical entrainment shear stress. The large clasts are analyzed for mean and maximum sizes from paleotsunami sand-sheets and at gullied or breached beach ridges, as shown in Figure 15.

Large clast sizes deposited in paleotsunami sand-sheets range from pebbles $(2 \mathrm{~cm}$ diameter) at sites $\mathrm{j} 70, \mathrm{j} 38$, and $\mathrm{j} 41$ to cobbles (5-12 cm diameter) at sites 822 and j44 (Table 4). One large cobble having a $20 \mathrm{~cm}$ diameter (Figure 15) was deposited in the $\mathrm{AD} 1700$ tsunami sand-sheet, lining a broad trough at $160 \mathrm{~cm}$ depth at site $\mathrm{j} 44$. The cobble was likely eroded from the Avenue $\mathrm{K}$ ridge breach, and then transported to the Newanna wetland site by shallow high-velocity flow that was directed from the ridge breach (Figure 14).

\section{Discussion}

6.1. Strategy for Constraining Tsunami Flow Hazards in the Beach Plain. Locally varying presence and absence of paleotsunami deposits on the landward side of stable beach ridges in the Seaside study area are used to estimate minimum runup heights and water column depths. Representative water column depths and measured ridge slopes are then used to calculate flow tractive forces. Resulting predictions of shear stress are independently tested using depositional records of clast entrainment. The topographic controls on water depth and flow force are then used to target the sites of greatest flooding hazard for evacuees in the study area.

6.2. Overtopping. Cobble ridge elevations and slope gradients are shown for several overtopping localities in Seaside. The seawardmost ridge crest at the Cove is $7 \mathrm{~m}$ elevation (Figure 16). GPR profiling [29] and topographic surveys of converging ridge crests at the northern edge of the Seaside 


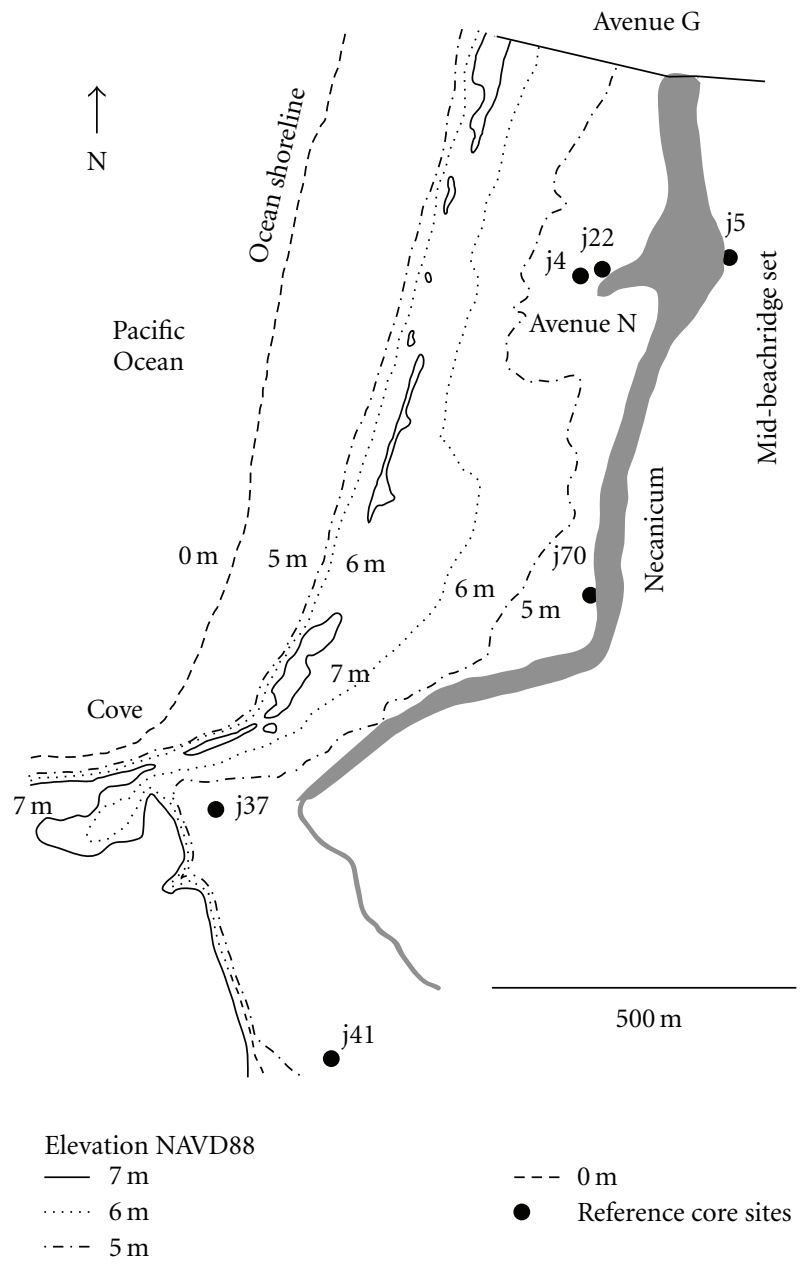

FIGURE 16: Seawardmost beach ridge topography in the south Seaside beach plain. Cobble ridge elevations are in meters NAVD88. The seawardmost beach ridge elevation at the Cove is $7.1 \mathrm{~m}$, corresponding to the $20 \mathrm{ft}$ NAVD29 contour. The seawardmost beach ridge elevation at Avenue N (6 m elevation) falls to the Necanicum channel ( $1 \mathrm{~m}$ elevation) in the Avenue $\mathrm{N}$ entrenchment feature, over a distance of $300 \mathrm{~m}$.

Cove demonstrate that the Cove beach ridges have prograded ( $\sim 100 \mathrm{~m}$ seaward distance) since closing off of the Cove wetlands before 2,780-2,950 yr BP (see core site j40b in Table 1). There is no significant elevation change across the ridge crests at the Cove, but the seawardmost ridge crests do decreases to $6 \mathrm{~m}$ elevation with 300-500 m distance northeast of the Cove. The substantial overtopping of the Cove beach ridges by paleotsunami events \#3 and \#5 (Figure 8) required flow elevations in excess of $8 \mathrm{~m}$ elevation at the Cove.

The anomalous entrenchment feature or gully at the Avenue $\mathrm{N}$ wetlands (Figure 9) is hypothesized to have resulted from paleotsunami overtopping and scour on the seaward slope of the Necanicum interridge valley (Figure 16). To test for such a gully erosion mechanism, the slope gradient (0.017) is established from the elevation change (five meters) between the seawardmost ridge crest ( $6 \mathrm{~m}$ elevation) and the Necanicum channel ( $1 \mathrm{~m}$ elevation) along a southwestto-northeast profile ( $300 \mathrm{~m}$ distance). See the following for tractive force calculations from overtopping flows.
Beach ridge overtopping by the smaller AD 1700 paleotsunami is established at 3rd Avenue (Area 5), Avenue $\mathrm{K}$ (Area 6), and the Palmrose midden (Area 1) (Figures 2, 6, 13, and 15). Overtopping at these locations requires flow(s) over the middle set of cobble ridges ( 5 m elevation) as shown in Figure 17. The very localized overtopping by the AD 1700 paleotsunami suggests flow depths of $\sim 1 \mathrm{~m}$. The overtopping flows of the older paleotsunami events, particularly those that breached the cobble ridges at 3rd Avenue, and Avenue $\mathrm{K}$, could have reached $2-3 \mathrm{~m}$ in water column depth. These flow depths are based on the seawardmost ridge overtopping height of at least $8 \mathrm{~m}$ elevation, as shown for paleotsunami events \#3 and \#5 at the Cove (Figures 8 and 16).

The gradient at the 3rd Avenue overtopping area (0.013) is taken from a southwest-northeast elevation change of $5 \mathrm{~m}$ to $1 \mathrm{~m}$ over a distance of $300 \mathrm{~m}$ (Figure 17). A lower gradient of 0.012 is measured from the Avenue $\mathrm{K}$ locality where the west-east slope of the beach ridge falls from $4 \mathrm{~m}$ to $1 \mathrm{~m}$ over a distance of $250 \mathrm{~m}$. The gradient at the Palmrose overtopping 

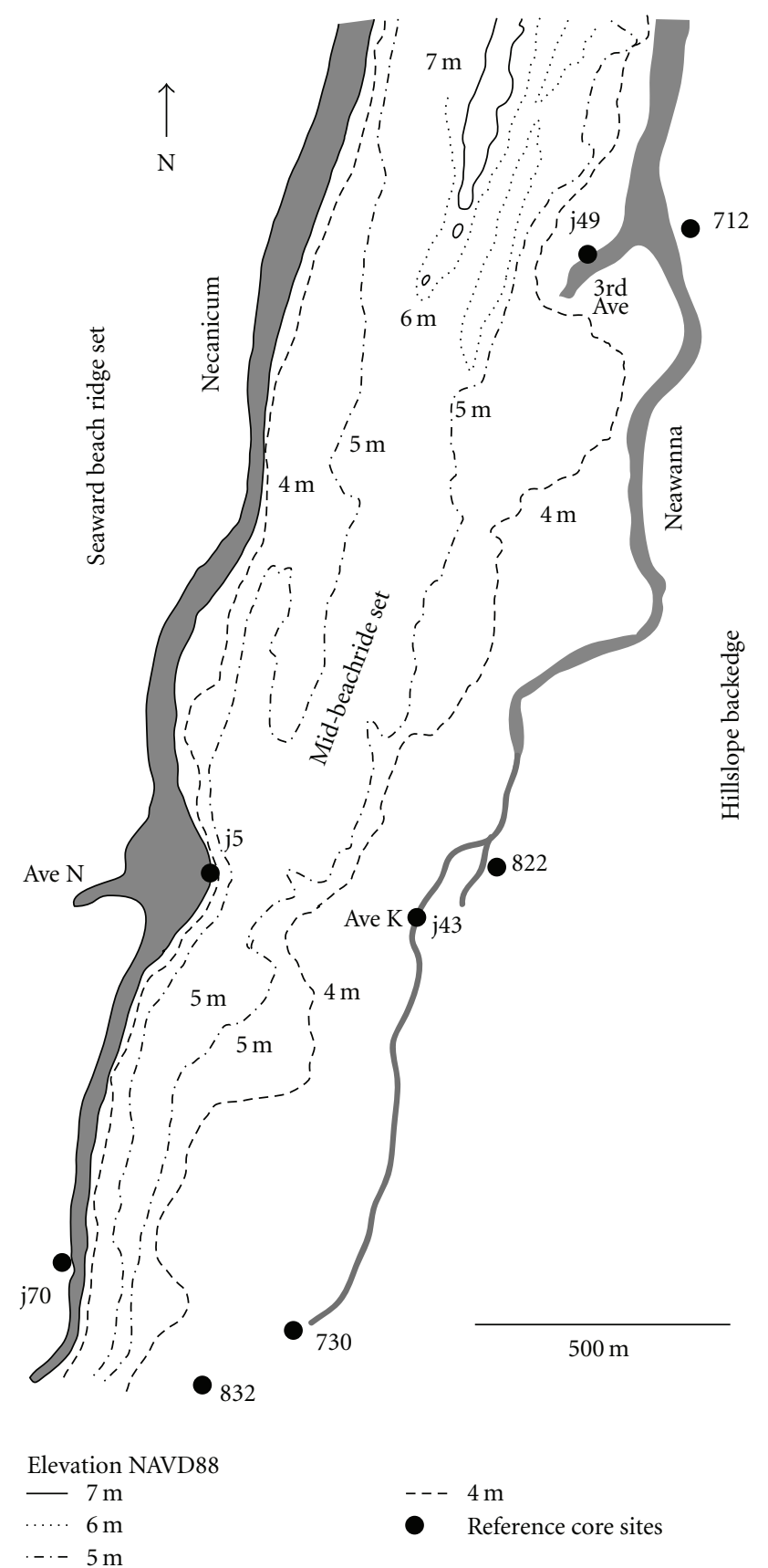

Figure 17: Topography of the middle beach ridge(s) separating the Necanicum and Neawanna interridge valleys in the Seaside beach plain. Cobble ridge elevations are in meters. The highest beach ridge divide ( $5 \mathrm{~m}$ elevation) falls to the Neawanna channel ( $1 \mathrm{~m}$ elevation) at the 3rd Avenue and $\mathrm{K}$ Avenue localities. A very broad ridge ( $4 \mathrm{~m}$ elevation) drops to the supratidal wetlands ( $3.5 \mathrm{~m}$ elevation) in the Palmrose bogs at site 832 .

locality is 0.002 , based on an elevation drop from $4 \mathrm{~m}$ to $3.5 \mathrm{~m}$ at site 832 over a west-east distance of $250 \mathrm{~m}$.

6.3. Bed Shear Stress. Paleotsunami tractive forces or bed shear stresses are estimated for the landward slopes of the overtopped beach ridges at Avenue N (Area 3), 3rd Avenue (Area 5), Avenue K (Area 6), and Palmrose (Area 1) (Table 5) using the modified DuBoys equation (Table 3 ). For this analysis, the water surface gradients on the landward side of the ridges are assumed to follow the local ground surface slopes. The calculations shown here are for a set of flow depths (0.5-2.0 $\mathrm{m}$ depth), spanning the lower range of expected values based on flow overtopping evidence, and on measured slope angles (Figures 16 and 17). A constant fluid density $\left(1000 \mathrm{~kg} \mathrm{~m}^{-3}\right)$ is assumed for the dilute flows, although bottom layers might be charged with sand-sheet flow. Estimated shear stress values increase with increasing flow depth $(0.5-2.0 \mathrm{~m} \mathrm{depth})$ and decrease 


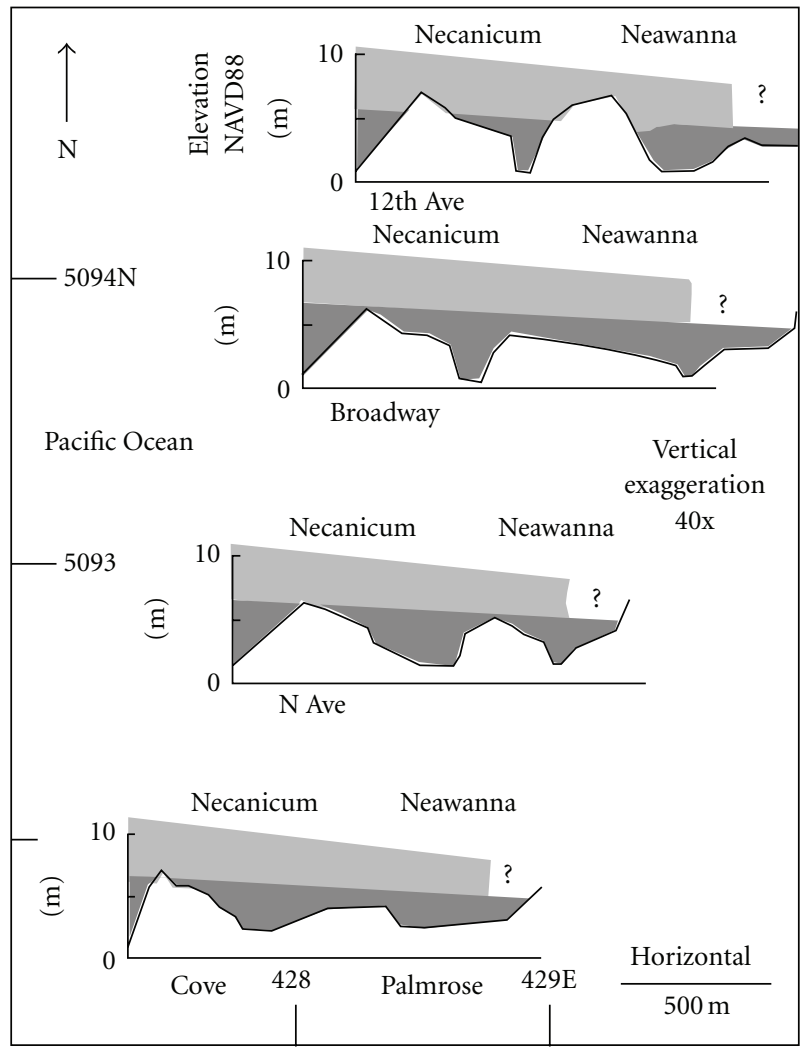

Event flooding
AD 1700
$1.3,2.6 \mathrm{ka}$

FIGURE 18: Paleotsunami flooding of selected topographic profiles in the Seaside beach ridge plain using the modest runup height of event $\# 1$ at $\mathrm{AD} 1700$, and the larger runups of events $\# 3$ and $\# 5$ at 1.3 and $2.6 \mathrm{ka}$, respectively.

with decreasing slope (0.017-0.002 gradient) at Avenue N (830-3,330 dyne $\mathrm{cm}^{-2}$ ), 3rd Avenue (640-2,550 dyne $\mathrm{cm}^{-2}$ ), Avenue K (490-1,960 dyne $\mathrm{cm}^{-2}$ ), and Palmrose (100390 dyne $\mathrm{cm}^{-2}$ ).

6.4. Critical Entrainment Shear Stress. Bottom shear stresses of paleotsunami flows are estimated from clasts deposited in paleotsunami sand layers or dislodged from breached ridges (Table 3). Plane bedded sand layers $(5-10 \mathrm{~cm}$ thick) lack large clasts at sites 867,712 , and 832 . These deposits are assigned bottom shear stress values of least 10 dyne $\mathrm{cm}^{-2}$ (Table 6), this minimum being based on deposition by sandsheet flow. Pebble transport at sites j70, j38, and j41 also requires bottom shear stress values of at least 10 dyne $\mathrm{cm}^{-2}$ as calculated from the entrainment of measured pebbles using the critical entrainment equations [24, 25]. Cobbles transported over thin sand beds $(\sim 1 \mathrm{~cm}$ thick) at sites 822 and j44 yield estimated bottom shear stress values of 1520 dyne $\mathrm{cm}^{-2}$. The largest clast observed in a thin sand-sheet deposit (20 cm diameter cobble at site j44) indicates a critical shear stress of 26 dyne $\mathrm{cm}^{-2}$. Relatively small shear stresses are required to roll rounded clasts over flat sand surfaces [30].

The erosion of cobbles in ridge entrenchments at Avenue $\mathrm{N}$, 3rd Avenue, and Avenue K require very large bed shear stresses of 660-1080 dyne $\mathrm{cm}^{-2}$, as calculated from mean cobble sizes in the eroded cobble ridges (Table 6). This is due to the large pivot angles that need to be overcome by the bed sheer stresses to roll cobbles over cobbles [23, $24]$. Dislodgements of the largest boulder sizes $(26-32 \mathrm{~cm})$ observed in the cobble ridges indicate shear stresses of 11301260 dyne $\mathrm{cm}^{-2}$. For this analysis we do not address the flow durations needed to unravel the flanks of the cobble ridges in the production of the tsunami breaches or coulees. However, rapid flooding of the interridge valleys probably limits the greatest flow gradients to the early phase(s) of inundation. Downslope flow velocity should approach low values when channels become filled with surge water. The timing of channel filling could depend on tsunami wave form(s), multiple wave trains, and backwash discharge between tsunami wave trains.

6.5. Paleotsunami Flooding Mechanisms. Paleotsunami inundation in the Seaside beach plain occurred by wide-scale overtopping of the seawardmost beach ridges (event \#3 at $\sim 1.3 \mathrm{ka}$ ) and by localized overtopping of the middle beach ridges (event $\# 1$ at $\mathrm{AD} 1700$ ) (Figures 18 and 19). Paleotsunami events \#3 and \#5 had shoreline runups of greater than $\sim 10 \mathrm{~m}$ elevation NAVD88 at the Cove when 

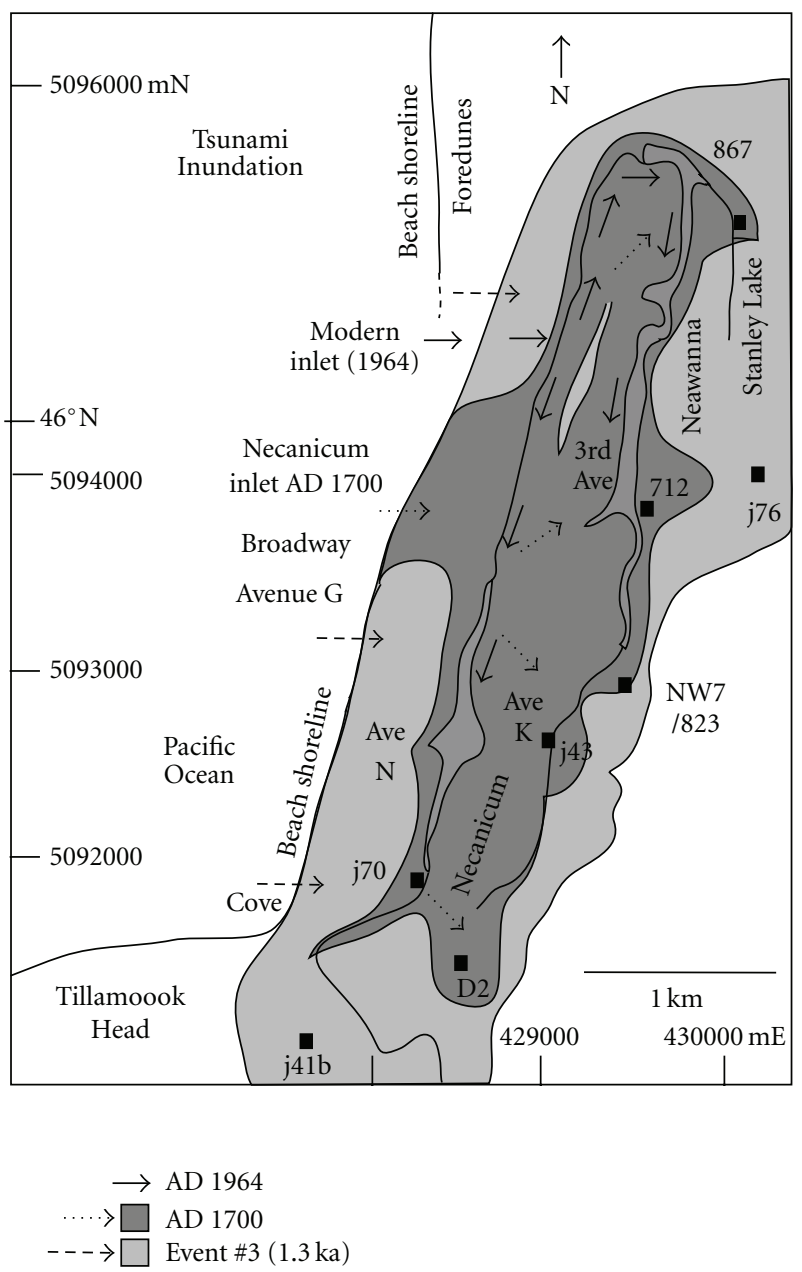

FIGURE 19: Map of tsunami inundation in Seaside, Oregon, for three events including historical farfield tsunami in 1964 (small arrows), the last Cascadia nearfield tsunami at AD 1700 (dark gray), and a larger Cascadia tsunami from rupture event \#3 at $1.3 \mathrm{ka}$ (light gray). The historical 1964 inundation was localized to modern tidal inlet (small arrows) and intertidal channels. The AD 1700 inundation entered a paleo-Necanicum tidal inlet to flood the interior beach ridge plain (medium arrows). The larger Cascadia paleotsunami at $1.3 \mathrm{ka}$ flooded the entire beach ridge plain, including the highest cobble beach ridges on either side of the tidal inlet (large arrows).

adjusted to corresponding lower sea levels of -1.3 to $-2.6 \mathrm{~m}$ at 1.3 to $2.6 \mathrm{ka}$ (assuming a net rate of relative sea-level rise of $1 \mathrm{~m} / 1000 \mathrm{yr})$. The $\mathrm{AD} 1700$ paleotsunami did not substantially overtop the Cove beach ridge at $7 \mathrm{~m}$ elevation. Instead, it entered the interior beach plain through the paleoNecanicum Bay mouth. The AD 1700 paleotsunami surges did overtop the middle beach ridges at $5 \mathrm{~m}$ NAVD88. In all cases the Necanicum and Neawanna interridge valleys (1$3 \mathrm{~m}$ NAVD88) were flooded to dangerous depths (3-5 m flow depth).

Paleotsunami tractive forces are established by bed shear stress (Table 5) and critical entrainment (Table 6) for several overtopping localities in Seaside. Flow depths of $\sim 1.0 \mathrm{~m}$ are sufficient to dislodge the largest clasts from the high gradient Avenue $\mathrm{N}$ and 3rd Avenue beach ridge localities where tsunami coulees formed (Figure 13). Greater depths are likely required to entrench the lower gradient Avenue K beach ridge, which shows only minor breaching. The very low-gradient slope at Palmrose is consistent with a lack of any entrenchment features in that broad flat beach ridge.

6.6. Implications for Tsunami Hazards and Tsunami Evacuation. The high shear stresses demonstrated by large clast unraveling (660-1,260 dyne $\left.\mathrm{cm}^{-2}\right)$ at tsunami coulee sites, Avenue N, 3rd Avenue and Avenue K (Figures 9, 13, and 15), indicate particularly dangerous flooding hazards in the steeper beach ridge slopes. Even the modest AD 1700 paleotsunami (6-7 $\mathrm{m}$ runup height) produced sand-sheet flow (at least 10 dyne $\mathrm{cm}^{-2}$ ) at four back-edge localities of the $1.5 \mathrm{~km}$ wide beach plain. Large floating structural debris in currents reaching 1,000 dyne $\mathrm{cm}^{-2}$ bed shear stresses would likely destroy unreinforced structures and prove fatal to evacuees trapped at congested bridge crossings. In the Seaside beach ridge plain, the interridge valleys are associated with the greatest water depths and the highest flow shear stresses produced during initial tsunami inundation(s). 


\section{Conclusions}

Different paleotsunami inundations of the Seaside beach ridge plain occurred by (1) wide-scale overtopping of the seawardmost beach ridges, (2) flooding through the paleoNecanicum bay mouth, and (3) localized overtopping of interior beach ridges. At least two paleotsunami reached runup heights of at least $10 \mathrm{~m}$, as adjusted for paleo-sea level. High-velocity inundation distances exceed the width of the beach plain at $1.5 \mathrm{~km}$. High bed shear stress is verified by transport of large clasts in the landward dipping slopes of several beach-ridge overtopping localities. Downslope currents combined with greater flooding depths in the interridge valleys could pose challenging conditions for evacuation over narrow bridges that span the beach plain channels. Vertical evacuation options in seismically- and tsunamiresistant structures that are built on the higher beach ridge crests might offer safer alternatives than attempting to cross interridge valley channels over crowded bridges.

\section{Acknowledgments}

Bob Peters performed core logging and radiocarbon sample submittal for paleotsunami core localities revisited in 2004 under the Tsunami Pilot Study Working Group study. Neal Maine coordinated the permissions for coring in Nature Conservancy wetland areas along the Necanicum and Neawanna channels in Seaside. Paul Komar provided valuable reviews of critical entrainment analyses performed in this study. Kennett Peterson provided paper-editing assistance. Radiocarbon dating support was provided by NOAA, through grants to Oregon Graduate Institute and through the Tsunami Pilot Study Working Group, 2006.

\section{References}

[1] J. F. Lander, P. A. Lockridge, and M. J. Kozuch, Tsunamis affecting the west coast of the United States 1806-1992, NGDC Key to Geophysical Records Documentation No. 29, National Geophysical Data Center, Boulder, Colo, USA, 1993.

[2] M. E. Darienzo, Late Holocene paleoseismicity along the northern Oregon coast, Ph.D. thesis, Portland State University, Portland, Ore, USA, 1991.

[3] M. E. Darienzo, S. Craig, C. D. Peterson, et al., "Extent of tsunami sand deposits landwarwd of the Seaside spit," Clatsop County, Oregon. Final Report to Clatsop County Sheriffs, 1993.

[4] B. K. Fiedorowicz, Geologic evidence of historic and preshistoric tsunami inundation at Seaside, Oregon, M.S. thesis, Portland State University, Portland, Ore, USA, 1997.

[5] B. K. Fiedorowicz and C. D. Peterson, "Tsunami deposit mapping at Seaside, Oregon, USA," Geoenvironmental Mapping, vol. 1, pp. 630-648, 2002.

[6] Tsunami Pilot Study Working Group, "Seaside, Oregon Tsunami Pilot Study-Modernization of FEMA flood hazard maps," NOAA OAR Special Report, NOAA/OAR/PMEL, Seattle, Wash, USA, 2006.

[7] R. B. Schlichting and C. D. Peterson, "Mapped overland distance of paleotsunami high-velocity inundation in backbarrier wetlands of the central Cascadia margin, U.S.A," Journal of Geology, vol. 114, no. 5, pp. 577-592, 2006.
[8] C. D. Peterson, K. M. Cruikshank, H. M. Jol, and R. B. Schlichting, "Minimum runup heights of paleotsunami from evidence of sand ridge overtopping at Cannon Beach, Oregon, Central Cascadia Margin, U.S.A," Journal of Sedimentary Research, vol. 78, no. 5-6, pp. 390-409, 2008.

[9] M. E. Darienzo, "The relationship between Holocene changes in sea level, geomorphology, and prehistoric Indian site abandonment and shell midden changes in the Seaside, Oregon area," Final Report to Research Heritage Associates, Eugene, Ore, USA, 1992.

[10] U.S. Coastal Survey, "U.S. Coastal Survey Section X1 Coast of Oregon between Latitudes 45॰58'and 47०03' including Nekanakum Creek \& Sea Side House," Sheet No. 2 of 1874, scale 1:10,000, Register No 1381, 1875.

[11] G. E. Phebus and R. M. Drucker, Archaeological investigations at Seaside, Oregon: An intermediate report on the excavations of two major archaeological sites at Seaside, Oregon, through September 1977, Seaside Museum and Historical Society, Seaside, Ore, USA, 1979.

[12] M. Stuiver and P. J. Reimer, "Extended 14C data base and revised CALIB 3.0 14C age calibration program," Radiocarbon, vol. 35, no. 1, pp. 215-230, 1993.

[13] M. Umitsu, C. Tanavud, and B. Patanakanog, "Effects of landforms on tsunami flow in the plains of Banda Aceh, Indonesia, and Nam Khem, Thailand," Marine Geology, vol. 242, no. 1-3, pp. 141-153, 2007.

[14] F. I. González, E. L. Geist, B. Jaffe et al., "Probabilistic tsunami hazard assessment at Seaside, Oregon, for near-and far-field seismic sources," Journal of Geophysical Research C, vol. 114, no. 11, Article ID C11023, 2009.

[15] J. C. Borrero, C. E. Synolakis, and F. Hermann, "Northern Sumatra field survey after the December 2004 great Sumatra earthquake and Indian Ocean tsunami," Spectra, vol. 22, pp. S93-S104, 2006.

[16] E. T. Barnett, Potential for coastal flooding due to coseismic subsidence in the central Cascadia margin, M.S. thesis, Portland State University, Portland, Ore, USA, 1997.

[17] D. K. Rankin, Holocene geologic history of the Clatsop plains foredune ridge complex, M.S. thesis, Portland State University, Portland, Ore, USA, 1983.

[18] F. Reckendorf, C. Peterson, and D. Percy, "Dune Ridges of Clatsop County," Department of Oregon Geology and Mineral Industries, Open-File Report O-01-07, Text and Interactive Map on CDROM, 2001.

[19] B. F. Atwater, S. Musumi-Rokkaku, K. Satake, Y. Tsuji, K. Ueda, and D. Yamaguchi, "The orphan tsunami of 1700: Japanese clues to a parent earthquake in North America," US Geological Survey Professional Paper, paper 1707, 2005.

[20] L. K. Woxell, Prehistoric beach accretion rates and long-term response to sediment depletion in the Columbia River littoral cell, M.S. thesis, Portland State University, Portland, Ore, USA, 1998.

[21] K. R. Wengler, "Photo Contour Map, Clatsop County, Oregon, North Coast Area, NW1/4 section. Scale 1:1,200; contour interval 2 feet," Prepared for Federal Emergency Management Administration, Flood Map Series, CH2M Hill, Corvallis, Ore, USA, 1973.

[22] A. Scheffers and D. Kelletat, "Bimodal tsunami deposits-a neglected feature in paleo-tsunami research," in Geographie der Meere und Kusten, G. Schernewski and T. Dolch, Eds., pp. 67-75, Coastline Reports 1, 2004.

[23] M. C. Miller, I. N. McCave, and P. D. Komar, "Threshold of sediment motion under unidirectional currents," Sedimentology, vol. 24, pp. 507-527, 1977. 
[24] P. D. Komar, "Selective gravel entrainment and the empirical evaluation of flow competence," Sedimentology, vol. 34, no. 6, pp. 1165-1176, 1987.

[25] P. D. Komar, "Flow-competence evaluations of the hydraulic parameters of floods: an assessment of the technique," in Floods: Hydrological, Sedimentological and Geomorphological Implications, E. Beven and P. Carling, Eds., pp. 107-134, John Wiley \& Sons, New York, NY, USA, 1989.

[26] B. F. Atwater, M. P. Tuttle, E. S. Schweig, C. M. Rubin, D. K. Yamaguchi, and E. Hemphill-Haley, "Earthquake recurrence, inferred from paleoseismology," in The Quaternary Period in the United States, A. R. Gillespie, S. C. Porter, and B. F. Atwater, Eds., pp. 331-350, Elvevier, Amsterdam, The Netherlands, 2004.

[27] R. B. Schlichting, Establishing the inundation distance and overtopping height of paleotsunami from late-Holocene geologic records at open-coastal wetland sites, central Cascadia margin, M.S. thesis, Portland State University, Portland, Ore, USA, 2000.

[28] A. G. Dawson and S. Shi, “Tsunami deposits," Pure and Applied Geophysics, vol. 157, no. 6-8, pp. 875-897, 2000.

[29] H. M. Jol, D. G. Smith, and R. A. Meyers, "Digital ground penetrating radar (GPR): a new geophysical tool for coastal barrier research (examples from the Atlantic, Gulf and Pacific coasts, U.S.A.)," Journal of Coastal Research, vol. 12, no. 4, pp. 960-968, 1996.

[30] A. Shields, "Application of similarity principles and turbulence research to bedload movement," 1936, Tranlated from Anwendung der Aehnlichkeitsmechanik und der Turbulenzforschung auf die Geschiebebewegung, Mitt. Preuss. Versuchsanst. Wasserbau Schiffbau, by W.D. Ott \& J.C. von Vcheten. Publications of California Institute of Technology. Hydrodynamics Lab. No. 167, pp. 37. 2006. 

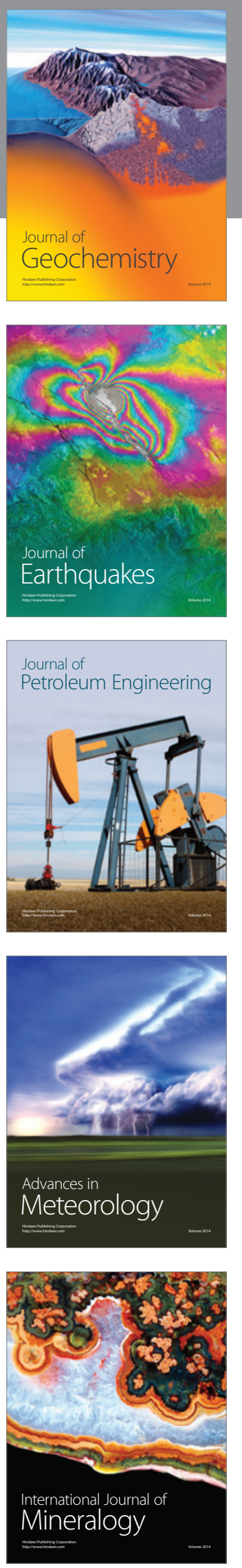
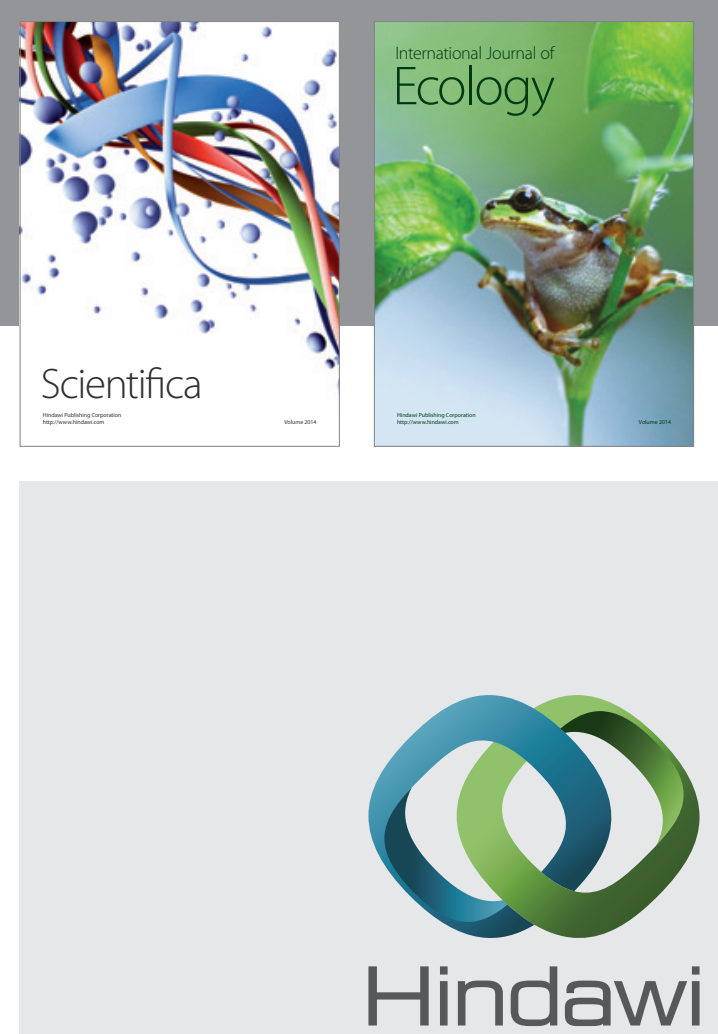

Submit your manuscripts at http://www.hindawi.com
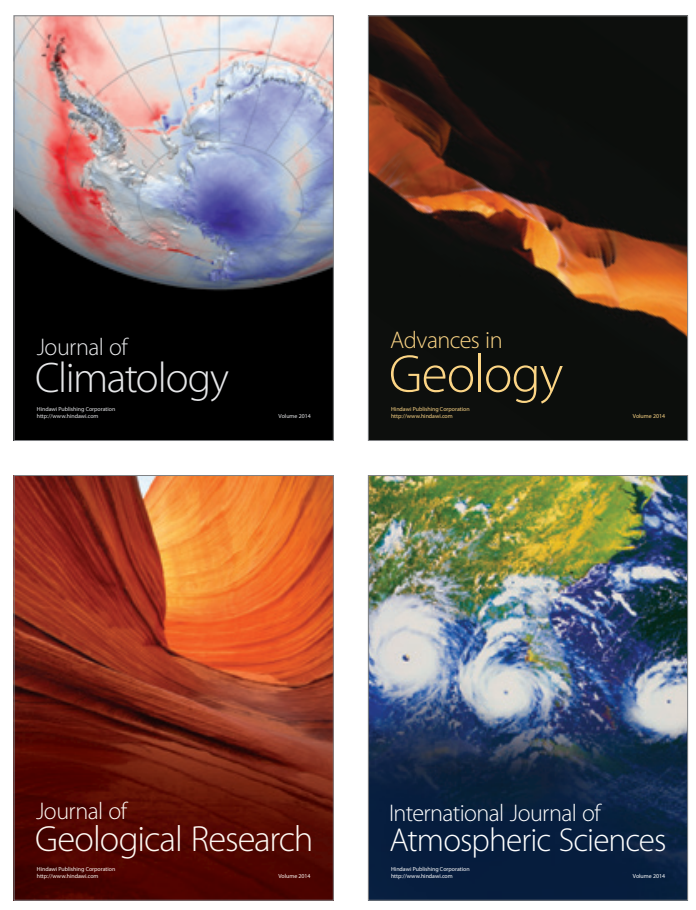
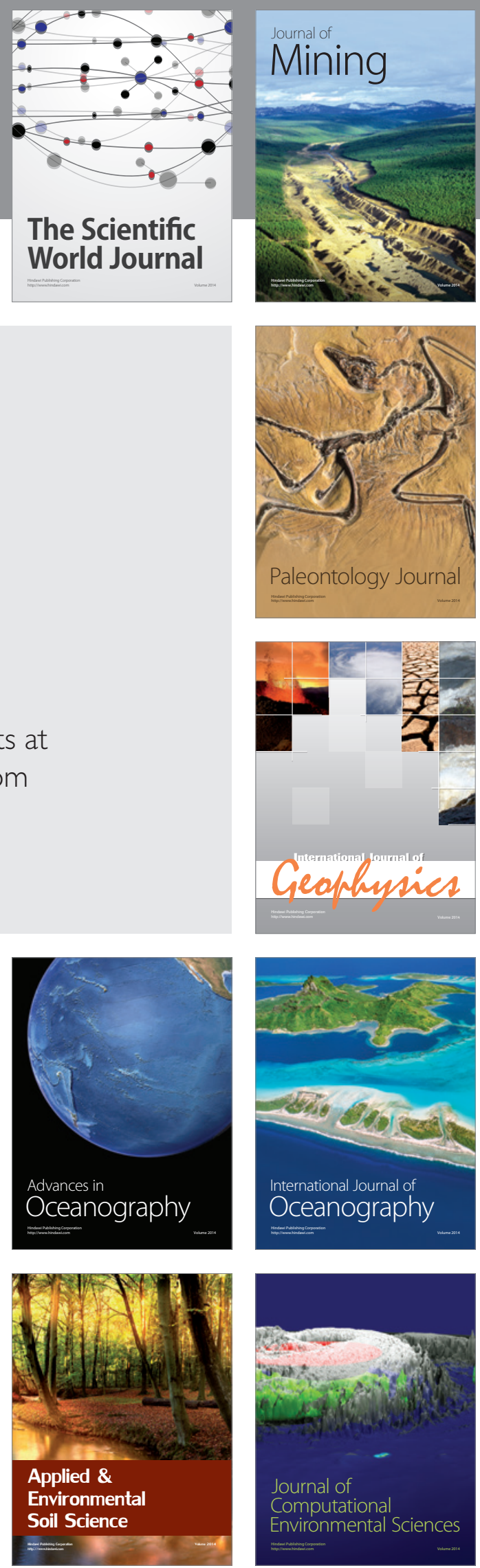